\title{
Hyolitha from the Early Paleozoic glacial erratic boulders (Geschiebe) of Germany and Poland
}

\author{
John M. Malinky* \\ San Diego City College, Physical Science Department, 1313 Park Boulevard, San Diego, CA 92131, U.S.A.
}

Received 6 March 2006, accepted 15 December 2006

Published 1 August 2007

With 7 figures

Key words: Hyolitha, Early Paleozoic, Germany, Poland, glacial erratics, operculum, epibionts.

\begin{abstract}
Hyoliths from glacial erratic boulders, or Geschiebe, from northern Germany and Poland include representatives of Hyolithes acutus Eichwald, 1840, the type of the genus. Geschiebe individuals of that taxon reinforce and augment the revised generic concept of Hyolithes of Malinky (2006), and extend the range of morphologic variation in terms of longitudinal sculptural elements and apical curvature. Occurrences in the Geschiebe of Crispatella Malinky, 2002 and Dorsolinevitus Syssoiev, 1958, reinforce the notion of distinct hyolith paleobiogeographic provinces in the Ordovician, with these forms belonging to the Baltic province of Marek (1976). Operculum A is the first operculum identified to possess an epibiont on the exterior. Hyolithes esthonus Koken, 1889 is herein transferred to Dorsolinevitus with question, and several other specimens are assigned to that genus but left in open nomenclature at the species level. Nevadotheca? sp. and Holmitheca? sp. are both recognized from Early Cambrian erratic sandstone boulders, suggesting that these forms lived in shallower, more nearshore environments than their occurrences elsewhere would suggest. "Hyolithes" vaginati (Quenstedt, 1852), the first hyolith species recognized from a boulder, is deemed unrecognizable due to inadequate preservation. The supposed Silurian hyolith Ceratotheca erratica (Koken, 1889 ) is herein transferred to the Gastropoda.
\end{abstract}

Schlüsselwörter: Hyolitha, Altpaläozoikum, Deutschland, Polen, Geschiebe, Operculum, Epibionten.

\section{Zusammenfassung}

Hyolithen aus Geschieben Norddeutschlands und Polens umfassen Exemplare von Hyolithes acutus Eichwald, 1840, der Typusart der Gattung. Die aus den Geschieben stammenden Exemplare dieser Art unterstützen und erweitern das Konzept der Gattung Hyolithes nach Malinky (2006) und führen weitere morphologische Variationen der longitudinalen Strukturelemente sowie der Krümmung des Apex ein. Das Vorkommen von Crispatella Malinky, 2002 und Dorsolinevitus Syssoiev, 1958 in Geschieben erweitert die bisherigen Kenntnisse der paläobiogeographischen Provinzen im Ordovizium. Diese Formen gehören zu der baltischen Provinz nach Marek (1976). Operculum A ist das erste Operculum mit einem Epibionten auf der Außenseite. Hyolithes esthonus Koken, 1889 wird in dieser Arbeit unter Vorbehalt Dorsolinevitus angeschlossen. Weitere Exemplare werden ebenfalls dieser Gattung zugeordnet, verbleiben aber auf der Artebene in offener Nomenklatur. Nevadotheca? sp. und Holmitheca sp. wurden aus unterkambrischen Sandstein-Geschieben bekannt. Das lässt vermuten, dass diese Formen in flachen, küstennahen Gewässern lebten, und steht damit im Widerspruch zu bisherigen Funden. Pugiunculus vaginati Quenstedt, 1852, der erste jemals aus einem Geschiebeblock bekannt gewordene Hyolith, ist für eine Bestimmung nicht ausreichend erhalten.

\footnotetext{
*E-mail: jmalinky@sbcglobal.net
} 


\section{Introduction}

Early Paleozoic limestone layers of Baltica are renowned as an especially prolific source of well-preserved invertebrate fossils. During the Pleistocene, boulders of these limestones, or Geschiebe, were transported to the south and deposited as part of glacial sediments in east-west trending belt in northern Germany and northwestern Poland (Fig. 1). These boulders were derived from the outcrop belt extending from the region of St. Petersburg, Russia in the east to southern Scandinavia in the west. Although the Early Paleozoic rocks in this region are easily correlative over long distances, separate sets of stratigraphic terminology have developed for the Ordovician rocks of Sweden, Estonia and for the Geschiebe (see Kröger 2004 for summary). Current terminology for the Geschiebe derived primarily from Hucke \& Voight (1967) is presented in Fig. 2.

The highly fossiliferous nature of certain boulders and the generally fine preservation of fossils have generated considerable interest among collectors since the mid- $19^{\text {th }}$ century when collecting from the Geschiebe began in earnest (see Patrunky 1928). Interest in these fossils has of necessity led to the establishment of several journals devoted exclusively to documentation of the fossils from the boulders. Enough is known at present about the material from the boulders and the in situ fossils from Baltica such that the Geschiebe specimens can be placed with precision in a modern stratigraphic context.
Compared to other invertebrates in the $\mathrm{Ge}$ schiebe, hyoliths are not common, although from time to time their occurrences have been noted and new species have been named. "Hyolithes" vaginati (Quenstedt, 1852) was apparently the first hyolith species described from a boulder, followed shortly thereafter by species named by Boll (1859), Remelé (1888) and Koken (1889). Holm (1893), who dealt solely with hyolith material from Scandinavia, made reference to the Geschiebe hyoliths in his classic study of hyoliths and conulariids. Since then, this material remained largely untouched, and even more recently collected hyoliths and other fossils from the Geschiebe remain to be documented properly. This study is a revision of the taxonomy, and reconsideration of the ecology and stratigraphic distribution of hyoliths from the Geschiebe.

\section{Localities and Repositories}

With several exceptions noted below, all hyoliths were discovered in glacial erratic boulders. Locality information given on the labels or in the literature associated with some of these specimens is sparse, with little more than the name of the nearest village or town, or some other major geographic feature such as a lake, being given. In many cases, the labels are more than a century old and unfortunately some critical pieces of information are now illegible or lost. As much information as can be deciphered is given with each species, including not only the

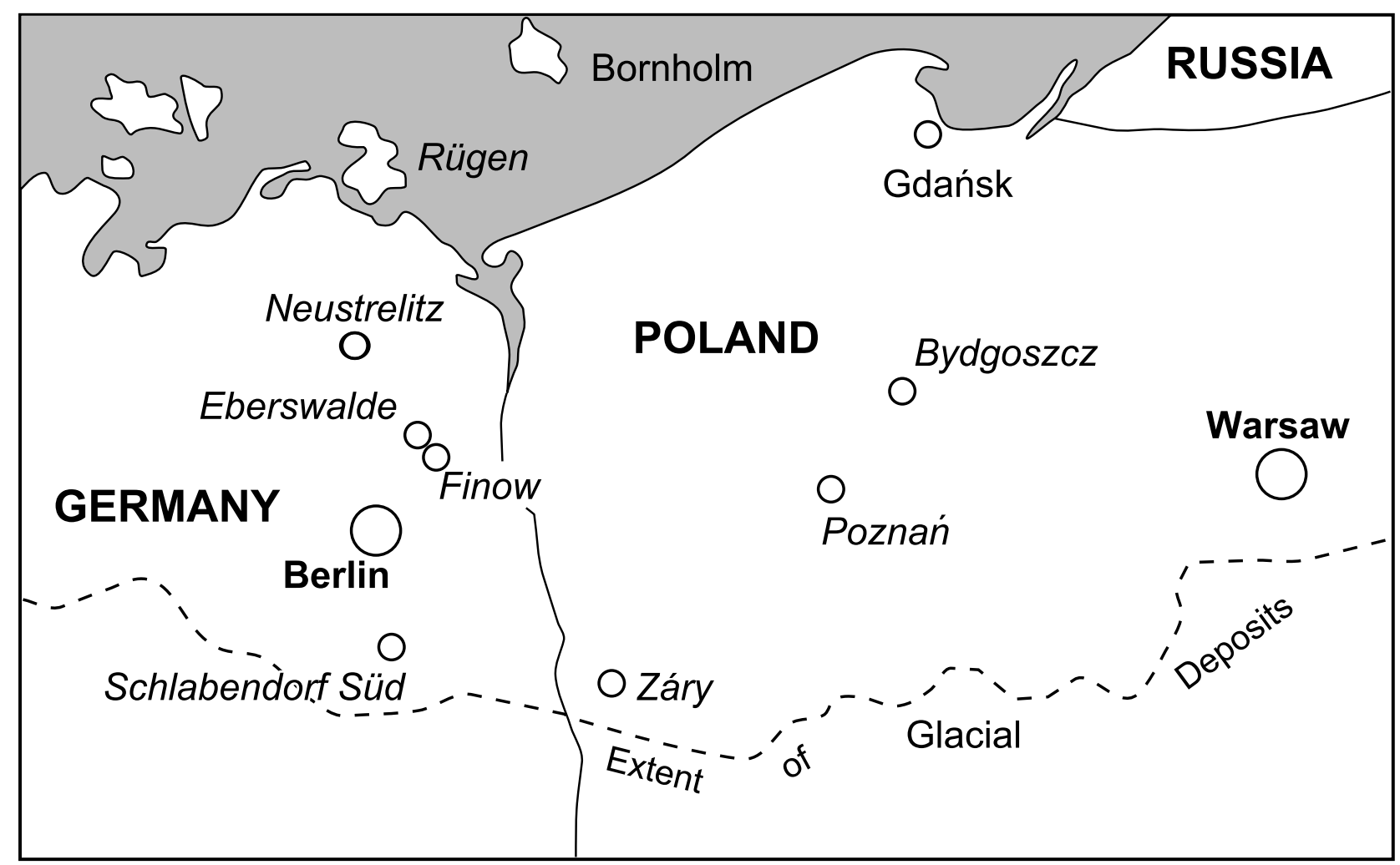

Fig. 1. Map showing localities (open circles) from which fossils in the Geschiebe or glacial boulders have been collected. 


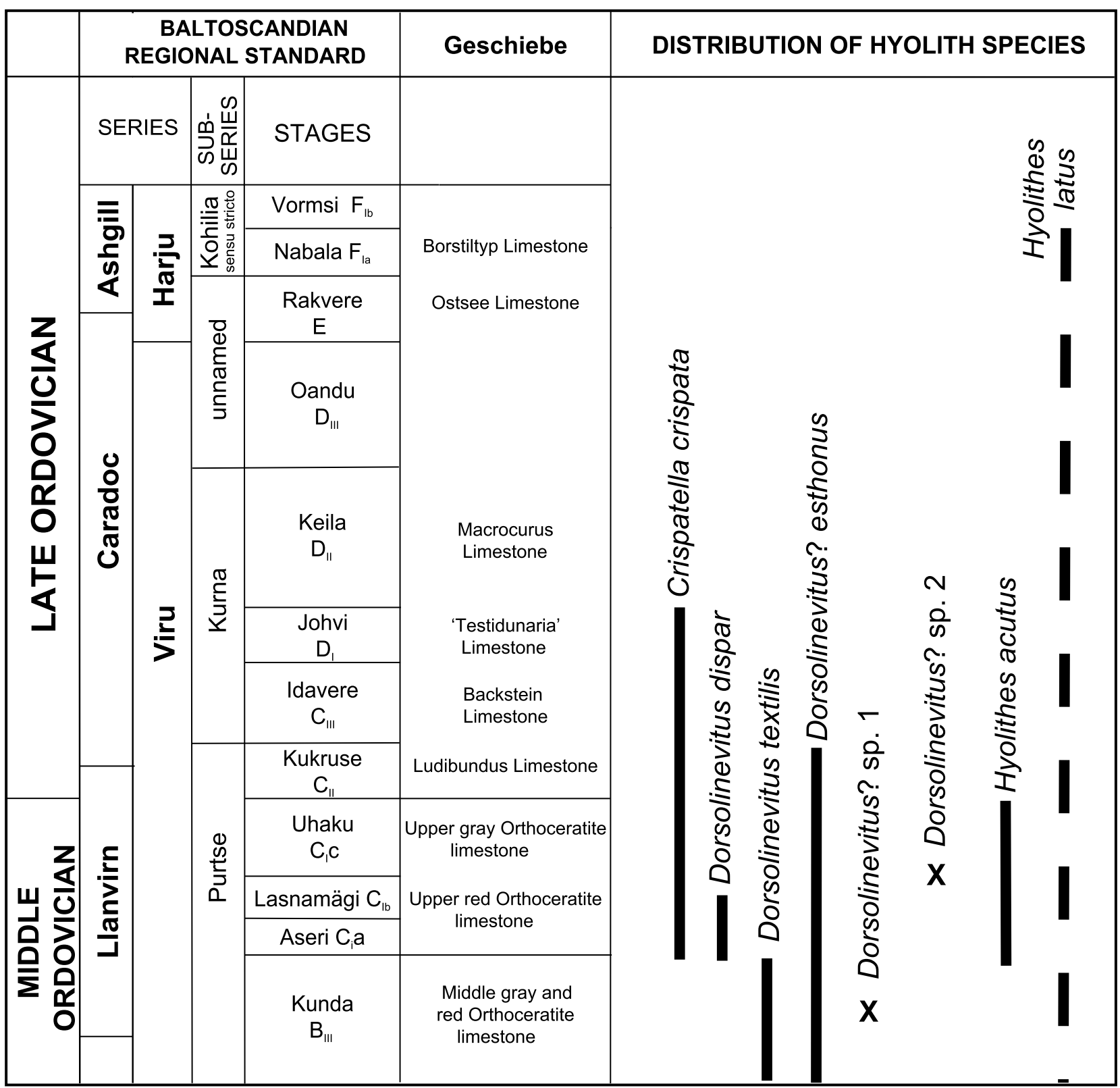

Fig. 2. Stratigraphic distribution of hyolith species discovered in the Geschiebe (after Dronov \& Holmer 1999 and Hucke \& Voight 1967).

locality and stratigraphic interval but the name of the collector and date of collection if known. Most of these specimens were discovered during road or building construction, or when plowing a field. Consequently there are no outcrops to visit and re-collect for additional material. However, many of these species have been reported from in situ occurrences in Sweden (Holm 1893; Malinky \& Berg-Madsen 1999; Berg-Madsen \& Malinky 1999; Malinky 2002) and Estonia (Holm 1893; Malinky 2003a), where their stratigraphic and geographic contexts may be directly observed.

All specimens with prefix $\mathrm{MB}$ are deposited in the Museum für Naturkunde der Humboldt-Universität zu Berlin; those with RM Mo are in the National Museum of Natural History, Stockholm, SGU indicates the Swedish Geological Survey, Upp- sala. Specimens under TU are housed in Tübingen, and those under PSU are in the Eichwald collection, St. Petersburg State University, Russia.

\section{Comments on Hyolith Paleobiology and Taphonomy}

Paleobiology: Various aspects of hyolith ecology have been addressed by Syssoiev (1959) and Fisher (1962), and more recently by Runnegar et al. (1975) and Marek \& Yochelson (1976), however, one trait commonly seen among the Geschiebe hyoliths requires additional comment. This is apical curvature toward the dorsum, epitomized by the curvature of some individuals of Hyolithes acutus (see Remelé 1889c, pl. 30: Figs 1b, 3a-b, 4a, 5a; Holm 1893, pl. 6: 
Fig. 23 and Fig. 5D herein). Dorsal curvature of the apical end was considered by Fisher (1962) to indicate a species that moved by a 'rocking' motion back and forth on the sea bottom. In contrast, this feature is here regarded as an adaptation to a soft, muddy substrate. The degree of curvature would have caused the center of gravity or buoyancy of the animal to shift such that the animal could have rested with greater stability both on and in the mud of the sea floor, and the aperture would have been elevated farther above the sea floor. Variation in curvature within one species may reflect adaptations to minor differences in softness of the sea floor, with more curved individuals living partly on and partly in softer substrates. Other Geschiebe individuals have relatively straight conchs, suggesting that they might have lived on a firmer sea floor where partial burial was neither necessary nor possible. Otherwise, a highly curved individual would not be stable on a firm substrate. Lateral curvature of the apex has not been seen among the hyoliths documented by Holm (1893) or herein, but is known in individuals from elsewhere (Malinky \& Sixt 1990), although its significance remains obscure.

Longitudinal elements of sculpture are also fairly common among the hyoliths from this region, and are a diagnostic trait for some taxa, such as several species of Hyolithes (Malinky 2003a, 2006). These elements may have aided the smooth flow of water over the conch, or perhaps served to strengthen and reinforce the shell, as is thought to be the case with various gastropod taxa (Ebbestad \& Peel 1997).

Epibionts are encountered only exceptionally on hyolith conchs, and overgrowths on the operculum were unknown until now. The exterior of one such operculum from the Geschiebe has a bryozoan partially covering its surface (Fig. 6A), present mostly on the conical shield with but a small portion on the cardinal shield. Perhaps when the epibiont was growing part of the cardinal shield was covered with sediment. Such attachments have been reported previously from hyoliths although only from conchs rather than opercula. Barrande (1867) and Novák (1891) documented Devonian hyoliths from the Barrandian region near Prague with such coverings, with revisions and interpretations of the paleobiologic significance of those occurrences given by Marek \& Galle (1976). Bassler (1911) used a bryozoan attached to a conch of Dorsolinevitus striatus (Eichwald, 1860) from the Upper Ordovician of Estonia as the type for Mesotrypa expressa Bassler, 1911. Malinky (1990) reported epibionts from the Upper Ordovician of the Cincinnati, Ohio (USA) region, with additional occurrences from Late Ordovician rocks in Estonia (Malinky 2003a). The operculum reported herein is thus far the only known specimen from the Geschiebe to possess an epibiont covering.

Geographic and temporal distribution: Marek (1976) recognized two distinct paleobiogeographic assemblages of hyoliths, a Baltic province that included northern Europe, and a Mediterranean province that encompassed southern Europe and northern Africa. Recent revisions of hyolith taxa from Sweden, Estonia and Scotland (Malinky \& Berg-Madsen 1999; Berg-Madsen \& Malinky 1999; Malinky 2002) have reinforced Marek's original conception of these provinces, which are now reinforced even further by the hyoliths documented herein. Representatives of Crispatella Malinky, 2002, Dorsolinevitus Syssoiev, 1958 and Hyolithes Eichwald, 1840 remain exclusively Baltic province hyoliths, and none of the taxa known from the Mediterranean province (Marek 1976) have been found in any boulder.

Owing to incomplete preservation of many specimens and uncertainty as to the exact stratigraphic position of some specimens, the stratigraphic range of a given species may be in doubt, and whether the ranges given in earlier works require modification cannot be determined. Hyolithes acutus Eichwald, 1840 and Dorsolinevitus dispar (Holm, 1893) seemingly possess short ranges, suggesting potential for correlation, but only on a regional basis because of the provincialism of these taxa first noted by Marek (1976) and reinforced herein. The fact that these species seem to have been short-lived suggests that evolution of at least some hyoliths was rapid.

Taphonomy: The few Geschiebe hyoliths documented below with aperture intact are disarticulated and lack the operculum and helens, although one unattached operculum is documented herein from the Geschiebe for the first time. Helens, if present, remain undiscovered or unrecognized. The fact that only one operculum is definitively known and no helens have been reported after nearly 150 years of collecting from the Geschiebe suggests that these skeletal pieces may have been widely scattered by winnowing and/or bioturbation. However, their destruction by turbulent water seems unlikely, as none of the hyolith conchs shows any signs of abrasion. Holm (1893) recognized that the conch and operculum of Hyolithus (Orthotheca) johnstrupi Holm, 1893 from the Lower Cambrian green shales of Bornholm, Denmark were apparently composed of different materials as evidence by differential preservation. Malinky \& Berg-Madsen (1999) extended this observation to explain why opercula and helens overall are much rarer than hyolith conchs, suggesting that differences in skeletal mineralogy were not confined to the Bornholm species but were much more widespread. Perhaps the explanation of the disparity in numbers of hyolith conchs versus opercula in the Geschiebe lies at least in part with mineralogical differences between these pieces.

A final remarkable trait of some Geschiebe hyoliths and some others from the Baltic region is the presence in many species of several distinct layers 
of shell, each of which may have its own pattern of longitudinal or transverse markings. The layers were first noted by Koken (1889), and recorded slightly later by Holm (1893), but have never been used since as an integral characteristic in the description of any hyolith species. The structure of the shell layers was used more recently by Syssoiev (1960), Runnegar et al. (1975), and Marek \& Yochelson (1976) in attempting to determine phylogenetic affinity of the Hyolitha. The presence of shell layers is noted here because of its potential taxonomic usefulness, as in the Pelecypoda (Carter 1989); it likewise possesses great potential for confusing one hyolith species for several, depending upon which layer of shell is exposed on the surface of a particular individual (see Boll 1859 and Holm 1893). Because the hyoliths from the Geschiebe constitute a relatively small data base concerning shell layers, knowledge of the layers is too limited presently for generalizations about the stratigraphic and environmental distribution of differences in layering, and their taxonomic significance. Without doubt, some species (such as Hyolithes acutus) possess at least three layers of shell; others seem to have fewer, although diagenetic obliteration of shell layers cannot be conclusively ruled out. It is worth noting that exfoliation of layers is thus far unknown in orthothecid hyoliths, although that data base is even smaller than that of the hyolithids at present, and indeed, the few orthothecids described below from the Geschiebe lack any traces of shell due to preservation.

The fact that the hyolith shell layers noted above exfoliate apparently has led to the establishment of synonym species based on partly exfoliated individuals, as with the species of Boll (1859; see Holm 1893; Malinky 2002). Differences in ornament on various shell layers may be so pronounced that specimens from which one or more layers was removed during preservation could easily be mistaken for separate species. Examination of other hyolith species from Baltica and elsewhere may also lead to synonymy of species based on the as yet largely unrecognized multiple shell layers and their tendency to exfoliate.

\section{Systematic Descriptions}

Phylum Mollusca Cuvier, 1797

Class Hyolitha Marek, 1963

Order Hyolithida Syssoiev, 1957

Family Crispatellidae Malinky, 2002

\section{Crispatella Malinky, 2002}

Type species: Theca crispata Boll, 1859

\section{Crispatella crispata (Boll, 1859)}

Fig. $3 \mathrm{~A}-\mathrm{H}$

1859 Theca granulata Boll: 162 (fide Holm, 1893).

1859 Theca striata Boll: 162 (fide Holm, 1893).

1859 Theca crispata Boll: 162 (fide Holm, 1893).

1888 Hyolithes inaequistriatus Remelé: 670, pl. 28: Figs 4a-b, 5 (non pl. 28: Fig. 6).

1889 Hyolithes vaginati. - Koken: 80, pl. 8: Figs 6, 6a-b.

1889a Hyolithes inaequistriatus Remelé: 430, Fig. 2a-c, ?3.

1889b Hyolithes inaequistriatus Remelé: 547, Fig. 2b (non Figs 1, 2a, 2c).

1893 Hyolithes crispatus. - Holm: 88, pl. 3: Figs 16-20, 36-52, pl. 5: Figs 42, 43, pl. 6: Fig. 28.

1946 Hyolithes inaequistriatus. - Sinclair: 77 (pars).

1946 Hyolithes crispatus. - Sinclair: 75.

1946 Hyolithes granulatus. - Sinclair: 76

1946 Hyolithes striatus. - Sinclair: 80.

1946 Hyolithus inaequistriatus. - Sinclair: 77 (pars).

1971 Hyolithes inaequistriatus. - Neben \& Krueger, pl. 20: Fig. 22.

1973 Hyolithes crispatus. - Neben \& Krueger, pl. 20: Figs 19-22.

Ne otype: SGU 5113 (Holm 1893, pl. 3: Figs 36-39), designated by Malinky (2002).

Type locality and horizon: Löt, Öland, Sweden, in the Holen Limestone, Kunda Stage (Middle Ordovician).

Material: MB.Hy.9a-b (part/counterpart) Fig. 3A-D; MB.Hy.12 (Fig. 3E-H); MB.Hy.27; MB.Hy.28a-b; MB.Hy.89.

Localities and horizons: MB.Hy.9a-b (part/counterpart) is from a boulder of Ordovician (Caradoc $\mathrm{D}_{1}$ ) age, collected by Otto from Žary (formerly Sorau), in southwestern Poland; MB.Hy.12 was collected by Remelé in Eberswalde from layer $\mathrm{C}_{1}$; MB.Hy.27 is from Glienicke bei Zossen; MB.Hy.89 has only Ordovician from Berlin given on the label. The labels of MB.Hy.28a-b and MB.Hy.29 are illegible.

Diagnosis: Crispatellid hyolith which on the same individual having shell covered with straight longitudinal lines or ribs in some places and with crenulated ornament elsewhere, on both dorsum and/or venter; cross section triangular.

Description: Conch orthoconic with flattened to slightly inflated venter, grading into tightly rounded lateral edges; dorsum generally low with broad central ridge and flanks adjacent to it only slightly inflated to nearly flat; ligula short with rounded anterior edge and sides that dip gently to aperture; lateral sinuses apparently shallow and dorsal rim orthogonal; cross section has a triangular shape.

Shell on dorsum possesses distinctive longitudinal ribs; they are generally fine and closely spaced with spaces between them equal in thickness to 1-2 ribs; ribs may be straight in some areas and crenulated in others, with the straight portion abruptly replaced by crenulations; the amplitude of the crenulations may vary within one rib with no apparent pattern. On venter longitudinal ribs are coarser and farther apart, and between some ribs one much finer rib may be present. Ventral ribs are predominantly straight although short lengths of low crenulations may be seen in some places. Ventral internal mold has low, widely and irregularly spaced transverse rugae in places; otherwise that surface is smooth. 
Discussion: This species is referred to Crispatella Malinky, 2002 owing to the crenulations in longitudinal ornament on the shell, which is a diagnostic trait of this genus not seen in any other hyolithid, but since discovered among orthothecid hyolith Trapezovitus dens (Holm, 1893) from the Ordovician of Sweden. The crenulated lines are a rare feature overall among hyoliths and their significance remains uncertain. Undoubtedly it represents some irregularities in the tissue of the shell-secreting mantle which varied in intensity from place to place as well as from time to time during shell formation, as it thought to have occurred among ammonites (Henderson et al. 2002). Equally unusual for a hyolithid is the absence of any transverse sculpture recording the successive positions of the aperture, which is a trait found more commonly among orthothecids. Conch form and sculpture of the Geschiebe specimens match well that of the type species, and therefore these individuals are referred to Crispatella crispatus (Boll, 1859). Formerly, this and several other individuals now recognized as distinct species were combined under Hyolithus inaequistriatus Remelé, 1888. Holm (1893) recognized the artificiality of this grouping and separated the types into Crispatella crispata (Boll, 1859) and Hyolithus cymbium Holm, 1893.

\section{Dorsolinevitus Syssoiev, 1958}

Type species: Hyolithus dispar Holm, 1893.

Included species: Hyolithes striatus Eichwald, 1860; H. textilis Holm, 1893; H. vomer Holm, 1893; Dorsolinevitus marri Malinky, 2003a; possibly H. esthonus Koken, 1889 and Dorsolinevitus? sp. A and B.

\section{Dorsolinevitus dispar (Holm, 1893) Fig. 3I-K}

1893 Hyolithus dispar Holm: 84, pl. 3: Figs 23-30.

1946 Hyolithus dispar. - Sinclair: 75.

1953 Hyolithus dispar. - Jannusson \& Mutvei: 11, 19.

1958 Hyolithus dispar. - Syssoiev: 188, pl. 6: Fig 3.

1959 Hyolithus dispar. - Syssoiev: 399.

1960 Hyolithus dispar. - Jannusson: 281.

1962 Hyolithus dispar. - Syssoiev: 39.

1963 Hyolithus dispar. - Jannusson: 38.
1971 Hyolithes cf. dispar. - Neben \& Krueger, pl. 19: Fig. 24

1973? Dorsolinevites (sic) dispar. - Larsson: 16, 80, table 4.

1973? Hyolithes cf. dispar. - Neben \& Krueger, pl. 19: Fig. 24.

1995 Dorsolinevitus dispar. - Qian \& Xiao: 220, Figs $133 \mathrm{a}-\mathrm{d}$.

Lectotype: RM Mo 8037 (Holm, 1893, pl 3: Figs 29-30, pl. 1: Figs 13-15), designated by Malinky (2002).

Type locality and horizon: From Sollerö, Dalarna, Sweden, in the Seby Limestone, Lasnamägi Stage (Middle Ordovician).

Material: MB.Hy.35 (Fig. 3I-K).

Locality and horizon: "Upper red Orthoceratite limestone", which is the Segerstad Formation, Aseri Stage, Middle Ordovician, collected by Remelé in Eberswalde.

Diagnosis: Dorsolinevitus with prominent longitudinal ribs on dorsum whereas the longitudinal ribs are faint on venter with equally faint, randomly positioned transverse growth lines superimposed on them; aperture oxygonal (from Malinky 2002).

Description: Conch cyrtoconic with apical curvature toward dorsum; venter broad and only slightly inflated grading into sharp, keel-like lateral edges; dorsum high and inflated with rounded central ridge; height of dorsum increases disproportionately from apical to apertural end of conch such that dorsum is higher relative to width of conch in apertural area; aperture oxygonal created by very broad and deep lateral sinuses; ligula short with rounded anterior edge and gently dipping sides.

Three layers of shell present; on dorsum and apparently on venter the outermost layer has distinct, closely spaced faint longitudinal ribs that are evenly spaced and equally prominent, with space between ribs equal to width of one rib, transverse growth lines randomly distributed and not present everywhere; where present these lines tend to be very fine; details of the second and inner most layer of shell cannot be discerned; internal mold of venter smooth.

Discussion: This species is represented by one specimen from the Geschiebe which measures $46 \mathrm{~mm}$ in length, and has an apertural width and height of $16 \mathrm{~mm}$ and $14 \mathrm{~mm}$ respectively; the apical angle is $18^{\circ}$. Preservation is sufficiently good to identify this specimen as Dorsolinevitus dispar (Holm, 1893) although much shell on the dorsum is lacking, and the second and third shell layers are exposed in only one small area and these layers are poorly preserved.

Fig. 3. Crispatella crispatus (Boll, 1859) from near Žary, Poland. MB.Hy.9a, A - dorsum, B - right lateral view of dorsum, C venter, $\mathbf{D}$ - impression of venter showing exterior ornamentation and fragments of two shell layers adhering to matrix, $\times 1.3$. Crispatella crispatus (Boll, 1859) from near Eberswalde, Germany. MB.Hy.12. E - dorsum, F - venter, G - right flank of dorsum, H - left lateral edge, × 1.4. Dorsolinevitus dispar (Holm, 1893), MB.Hy.35 from near Eberswalde, Germany. I venter, $\mathbf{J}-$ right lateral view, $\times 1$ 1.3. K - cross section at $\times$ 1.6. Dorsolinevitus textilis $($ Holm, 1893) from near Bydgoszcz, Poland. MB.Hy.32.1, $\mathbf{L}-$ apical region showing longitudinal ribs on shell, at $\times 1.7, \mathbf{M}-$ dorsum, $\times 1.5$. Dorsolinevitus textilis (Holm, 1893) from near Bydgoszcz, Poland. MB.Hy.32.4, N - longitudinal ribs on dorsum, $\times 2$. Dorsolinevitus textilis (Holm, 1893) from near Bydgoszcz, Poland. MB.Hy.32.3, O - dorsum, P - right lateral edge, $\times 2$. MB.Hy.31.1 locality unknown. $\mathbf{Q}-$ venter, $\times$ 2. Dorsolinevitus textilis (Holm, 1893), MB.Hy.31.2 from near Bydgoszcz, Poland. $\mathbf{R}-$ dorsum showing constriction midway between aperture and apex, $\times$ 2. MB.Hy.32.2 from near Bydgoszcz, Poland. S - venter, $\times 2$. Dorsolinevitus sp. A, unnumbered from near Bydgoszcz, Poland. $\mathbf{T}$ - venter, $\mathbf{U}-$ left lateral edge and $\mathbf{V}-$ dorsum, $\times 1.2$. 

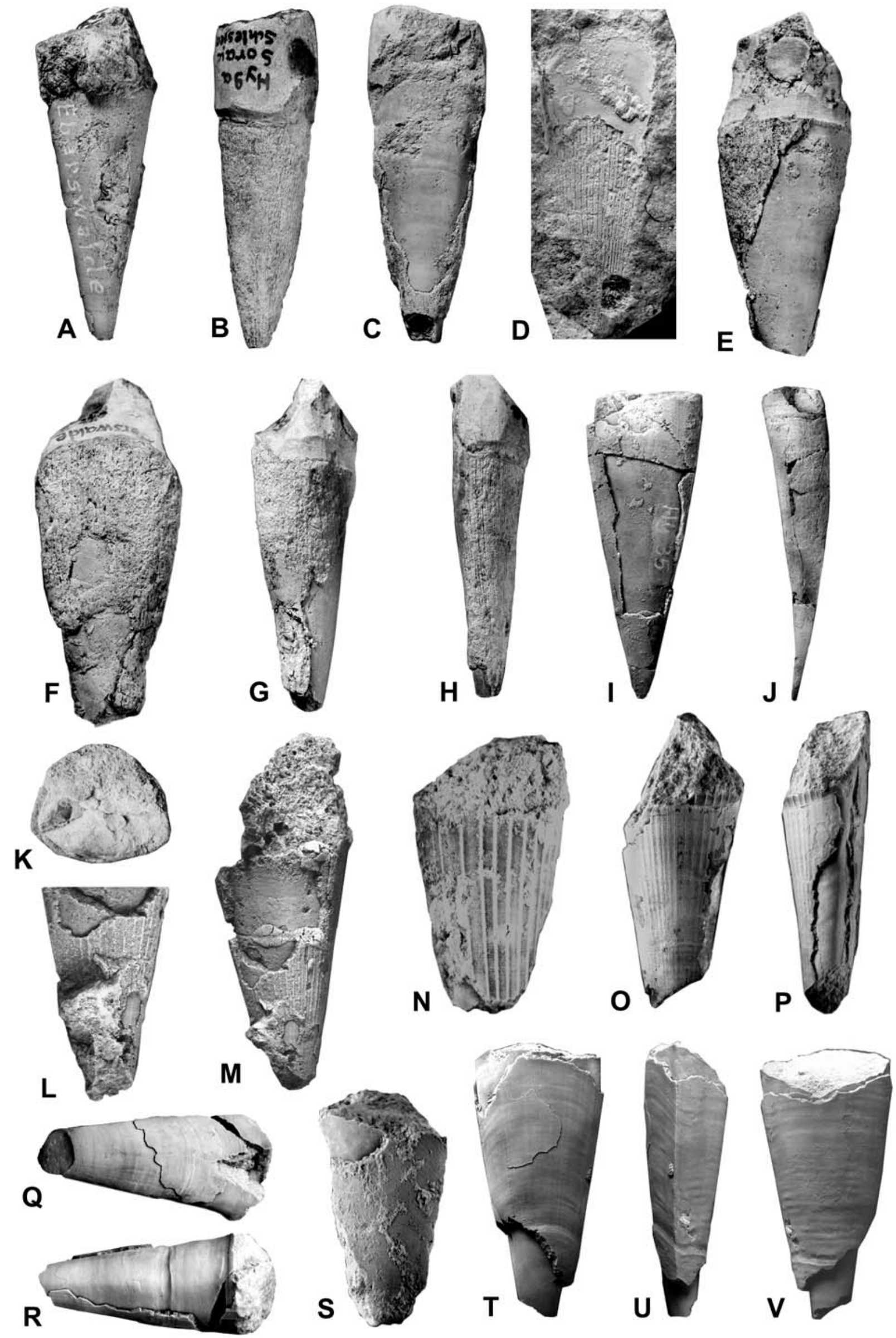
Holm (1893) reported that this species lacked longitudinal lines on the 'dorsum' (equals venter herein) but they are clearly present on the type specimens from Sweden, and faint traces of these remain on the weathered dorsum of the Geschiebe specimen. He also reported that some of the longitudinal lines near the lateral edges were "wavy" in appearance, but this has not been observed on the Geschiebe specimen. Additionally, Holm (1893) stated that a variety of this species, Dorsolinevitus dispar var. crassus Holm, 1893, agrees in ornament with $D$. dispar, but on the former the dorsal curvature is less, and the dorsum is higher and more narrowly rounded, creating a more inflated transverse outline. Morphology of the Geschiebe specimen agrees more closely with the "normal" form of D. dispar rather than with that of the subspecies.

Dorsolinevitus dispar (Holm, 1893) may be easily distinguished from D. textilis (Holm, 1893) by the finer, more closely spaced longitudinal lines on the former; D. textilis possesses widely spaced coarse ribs on the dorsum and transverse growth lines only on the venter. Dorsolinevitus vomer (Holm, 1893) possesses longitudinal lines in the central region of the dorsum; adjacent to the lines are narrow longitudinal areas with no longitudinal or transverse sculpture. Dorsolinevitus marri Malinky, 2003a is distinguished by a conch much larger than that of any other species of Dorsolinevitus. Dorsolinevitus? esthonus (Koken, 1889) may be separated from the others of this genus by the combination of coarse and fine longitudinal ribs on the dorsum, and coarse to fine growth lines in the apertural region of the venter. Comparisons with the incompletely preserved Dorsolinevitus sp. A and B are made at the appropriate places under the discussion of those species.

\section{Dorsolinevitus textilis (Holm, 1893)}

\section{Fig. 3L-S}

\author{
1893 Hyolithus textilis Holm: 82, pl. 3: Figs 31-35. \\ 1896 Hyolithes textilis. - Koken: 402. \\ 1946 Hyolithes textilis. - Sinclair: 80. \\ 1951 Hyolithes textilis. - Jannusson \& Mutvei: 633. \\ 1962 Dorsolinevitus textilis. - Syssoiev: 40. \\ 1967 non Hyolithus textilis. - Heidrich: 29, 31, Fig. 8 \\ 1973 Hyolithes textilis. - Neben \& Kruger, pl. 19: Fig. 23.
}

Lectotype: RM Mo 8048 (Holm 1893, pl. 3: Figs 31-35, pl. 2: Figs 2-5), designated by Malinky (2002).

Type locality and horizon: Utby in Dalarna, Sweden, from the Holen Limestone, Kunda Stage, Middle Ordovician.

Material: MB.Hy.31.1 (Fig. 3Q); MB.Hy. 31.2 (Fig. 3R) and ten fragments under MB.Hy.31.3 to MB.Hy. 32.12; MB.Hy.32.1 (Fig. 3L-M), MB.Hy.32.2 (Fig. 3S); MB.Hy 32.3 (Fig 3O-P); MB.Hy.32.4 (Fig. 3N).

Localities and horizons: Locality unknown due to illegible label for MB.Hy.31.1; MB.Hy. 31.4-MB.Hy. 31.12 and for MB.Hy.32.1-MB.Hy.32.4; MB.Hy.31.2 and MB.Hy.31.3 from the Ordovician $\mathrm{B}_{3}$, which is the Kunda Stage (Middle Ordovician) from near Bydgoszcz, Poland, collected by Petrunky.

Diagnosis: Dorsolinevitus with widely spaced generally coarse longitudinal ribs on dorsum with interspaces equal in width to 5-7 ribs; growth lines faint to absent on dorsum but prominent on venter whereas ribs are lacking on that side; aperture oxygonal and cross section lenticular.

Description: Conch orthoconic or cyrtoconic with slight curvature toward dorsum; venter flattened or slightly inflated and grading into keel-like lateral edges; dorsum varies from low to high with tightly rounded to sharp, keel-like central ridge; adjacent flanks vary from straight and steeply dipping to only slightly inflated with a more gentle angle of dip near the lateral edges; aperture has a poorly developed oxygonal shape with only shallow lateral sinuses, and the ligula is short and only slightly rounded at anterior edge; the sides of the ligula dip gently toward the aperture.

Outermost layer of shell on venter seemingly smooth or with faint transverse lines or rugae; these features, if present, are widely spaced with no regularity in spacing and are entirely absent on some individuals; inner layer of shell appears smooth. Outer layer of shell on dorsum with distinct longitudinal ribs that are widely spaced and have vertical sides, with interspaces equal in width to 5-7 ribs; shell surface between the ribs may be smooth or with fine, closely spaced transverse lines which continue from one interspace to the next; these are lower than the longitudinal ribs and do not cross the ribs themselves. Second layer of shell on dorsum has longitudinal ribs of slightly less pronounced character than those on the outermost layer, and there is a direct correspondence in number and position of ribs on both shell layers.

Discussion: All Geschiebe specimens assigned to this taxon are incomplete and missing shell to varying degrees. None has a complete apical or apertural region. Nonetheless, enough shell remains on all to support placement under Dorsolinevitus textilis (Holm, 1893). The description given above is a composite based largely on specimens MB.Hy.31.2, MB.Hy.31.3, MB.Hy.32.3 and MB.Hy.32.4. Despite incomplete preservation, the specimens mentioned above increase knowledge of the range of morphologic variation within this species. The height of the dorsum varies considerably (MB.Hy.32.2 and MB.Hy.32.3); the shell becomes thinner along the apertural rim, as evidenced by a flaring of the internal mold, apparently to accommodate an expansion in the soft tissue of the animal. Furthermore, some individuals are cyrtoconic with curvature toward the dorsum, whereas others have a straight, orthoconic conch. This may be an adaptation to microenvironmental differences in softness of the substrate, with the curved individuals living on the softer substrate where a shift in the center of mass and/or buoyancy by curving was necessary to allow the an- 
imal to keep the apertural region above the sediment/water interface.

Differences between this species and the others assigned to this genus were discussed above under Dorsolinevitus dispar.

\section{Dorsolinevitus? esthonus Koken, 1889 Fig. 4F-K}

1889 Hyolithes esthonus Koken: 81, pl. 8: Figs 4, 4a.

1946 Hyolithes esthonus. - Sinclair: 76.

Holotype: MB.Hy.7 (Fig. 4F-K), by monotypy.

Type locality and horizon: Near Tallinn, Estonia collected by von Schlotheim, exact level uncertain, Lower or Middle Ordovician.

Description: Conch cyrtoconic with slight dorsal curvature in apical region; venter slightly inflated and grading into rounded lateral edges; dorsum with highly inflated central ridge having slightly convex adjacent flanks; apertural rim appears orthogonal and ligula seems short with gently dipping sides; cross section triangular near apertural end but becoming lenticular in apical region; ligula, lateral sinuses, helens and operculum unknown.

Conch possesses at least two layers of shell; on the venter the outermost layer has longitudinal ribs; the ribs are of two kinds: a pronounced, thin though high-standing variety with steeply sloping sides; the intensity of these varies from place to place in no discernible pattern. A second variety is low but with nearly vertical sides, and these have the same intensity everywhere on venter; the spaces between all ribs is equal to the width of about one rib. Coarse transverse growth lines are present on the shell in apertural region of venter; these are irregularly spaced and are of the same morphologic character as longitudinal ribs with the near vertical sides; they cut across the longitudinal ribs to produce a cancellate ornament on the shell. On the dorsum the outermost layer of shell has exceedingly fine longitudinal lines with widely spaced transverse rugae superimposed on them in the apertural region; the rugae are low with flat tops, and the intervening spaces are equal in width to approximately one ruga. Second layer of shell has a Runzelschicht (see Malinky \& Mapes 1983) on dorsum. Internal mold appears smooth without any markings.

Discussion: The sole specimen of this species is $43 \mathrm{~mm}$ in long, and has an apertural height and width of $14 \mathrm{~mm}$ and $20 \mathrm{~mm}$ respectively; the apical angle is $24^{\circ}$. It is assigned to Dorsolinevitus owing to the longitudinal elements of sculpture on the shell, which are diagnostic of that genus, but with question because the overall preservation is poor and certain critical features, especially of the aperture, are not fully known. It resembles most Dorsolinevitus dispar, but the longitudinal ribs on the shell are far more pronounced and distinctive on D. dispar, whereas without question they are considerably finer, especially on the dorsum of D.? esthonus.

This specimen appears to have at least two layers of shell, with the both having exfoliated in most places to expose the internal mold. Markings on both layers were well illustrated by Koken (1889). In certain places it is impossible to determine precisely which shell layer possesses a particular feature because of preservation. Likewise, important details of the apertural region are lacking. The traits that serve to separate this species from the others referred to Dorsolinevitus were given above under $D$. dispar.

\section{Dorsolinevitus sp. A}

Fig. 3T-V, 4A

\section{Material: MB.Hy.unnumbered (Figs 3T-V, 4A)}

Locality and horizon: Near Bydgoszcz, in northwestern Poland, collected by Petrunky from the Middle Ordovician, $\mathrm{B}_{3}$, Kunda Stage.

Description: Conch with only slightly inflated venter, grading into sharp, keel-like lateral edges; dorsum high with rounded median ridge and flanks adjacent to it that are nearly straight and dip at a low angle toward the lateral edges. Conch slightly cyrtoconic with curvature toward dorsum. Aperture seemingly orthogonal with broad shallow lateral sinuses; ligula apparently short with gently dipping sides and broadly rounded anterior edge.

At least two layers of shell are present, and on the venter the outermost possesses a combination of fine equally spaced longitudinal lines and some wider, more pronounced longitudinal lines. On the dorsum the shell has fine, closely spaced longitudinal ribs with interspaces nearly equal in width to one rib. The second layer of shell has longitudinal lines on the venter similar to that seen on outer shell layer, whereas on the dorsum the fine longitudinal lines are lacking on the second shell layer. Low, widely and irregularly spaced rugae occur on both dorsum and venter with no apparent pattern in terms of variations of intensity. The internal mold is smooth and the shell decreases in thickness from apical to apertural regions.

Discussion: This species is represented by one specimen that is $42 \mathrm{~mm}$ long, and has an apertural width and height of $19 \mathrm{~mm}$ and $13 \mathrm{~mm}$; the apical angle is $20^{\circ}$. The outermost layer of shell is missing in most places except for one small area in the apertural region on dorsum and venter; the second layer is present everywhere except in the apical area. Both apical and apertural terminations of the conch are lacking, and the character of the aperture has been inferred from the transverse rugae on the inner layer of shell. 

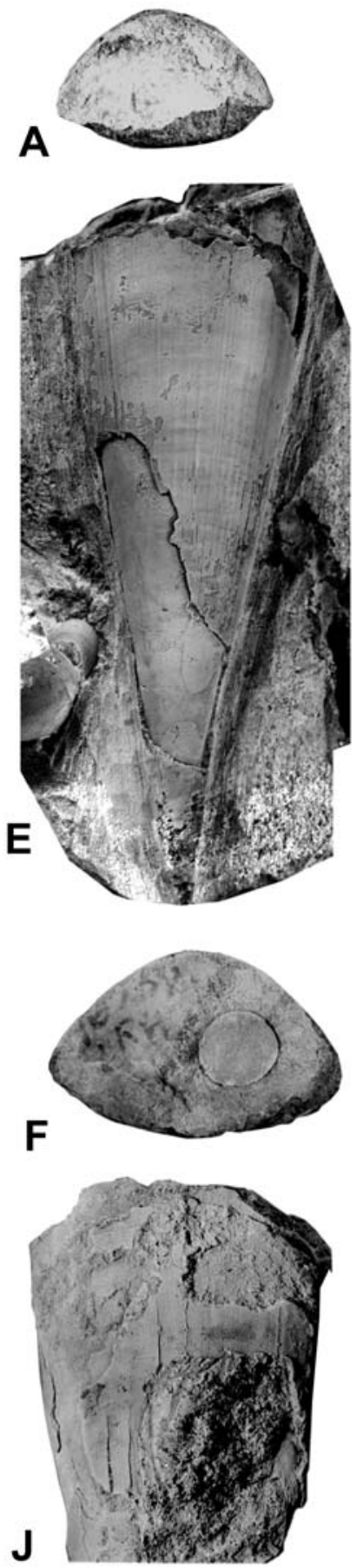

O

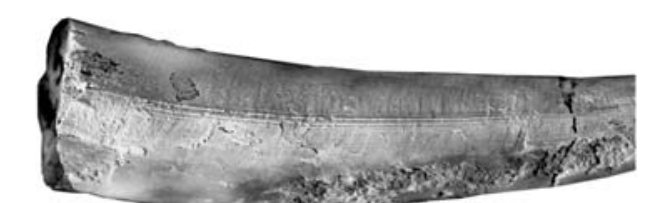

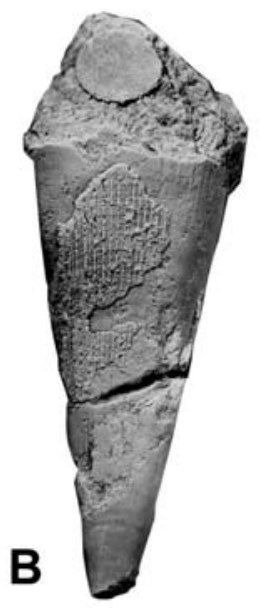
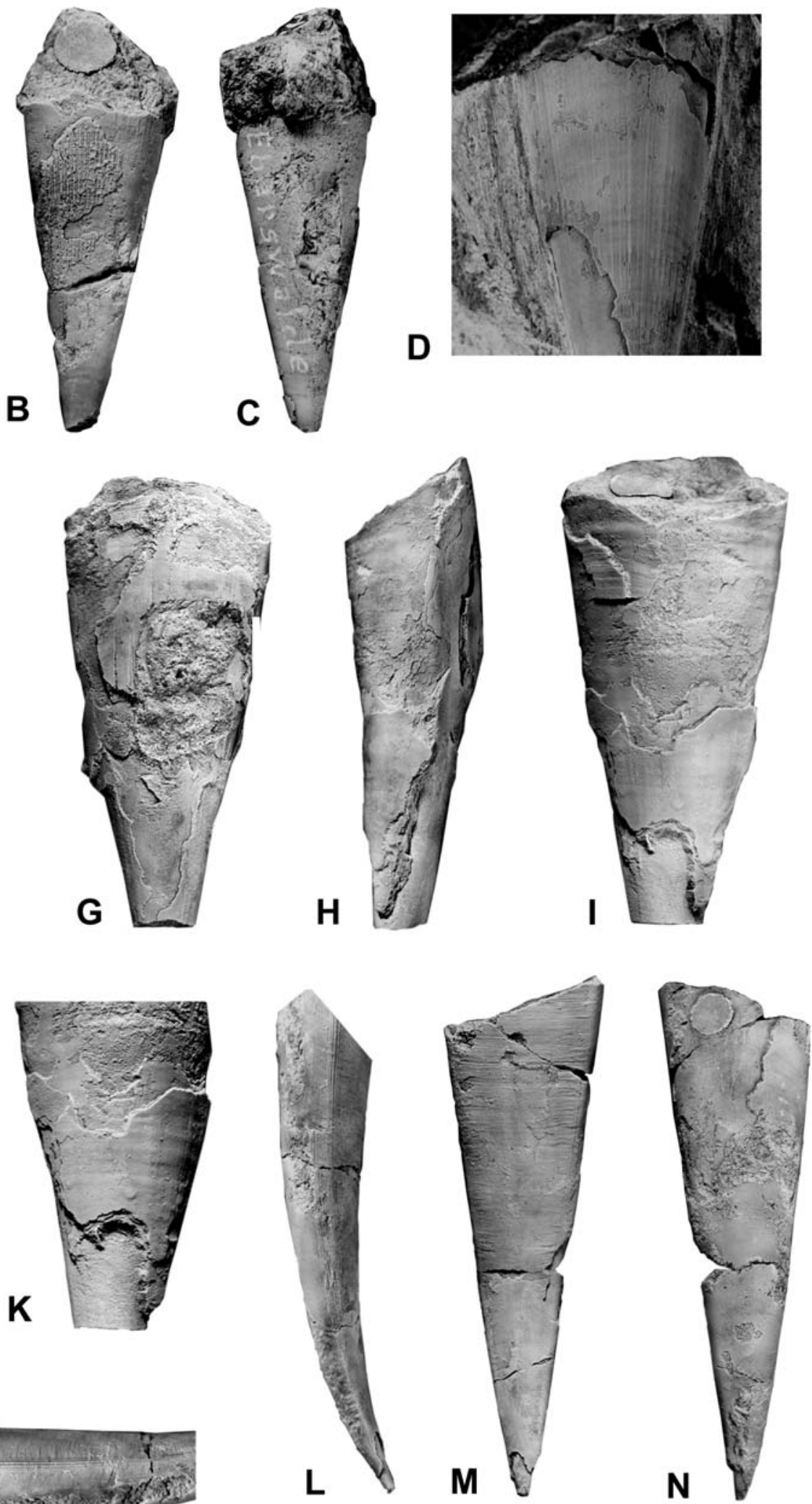

$\mathbf{N}$

Fig. 4. Dorsolinevitus sp. A from near Bydgoszcz, Poland. Unnumbered, A - cross-section, $\times 1.3$. Dorsolinevitus sp. B. from Eberswalde, Germany. MB.Hy.10, B - venter, C - dorsum, $\times 1.6$. Dorsolinevitus sp. B. from near Lake Hiddensee on the island of Rügen, Germany. MB.Hy.22, D - enlarged view of apertural region of venter, $\times 2$. E - view of entire venter showing longitudinal ribs on exterior of shell and smooth internal mold, $\times 1.8$. Dorsolinevitus? esthonus (Koken, 1889) from near Tallinn, Estonia. MB.Hy.7, F - cross-section, $\times 1.6$. G - venter, $\mathbf{H}$ - right lateral edge, $\mathbf{I}$ - dorsum, $\times 1.4$, J - enlarged view of ventral apertural region, $\times 1.8, \mathbf{K}-$ enlarged view of ventral apical region, $\times 1.8$. Hyolithes acutus Eichwald, 1840 from Neustrelitz, Germany. MB.Hy.3, $\mathbf{L}$ - left lateral edge, $\mathbf{M}$ - venter, $\mathbf{N}-$ dorsum, $\times 1.1, \mathbf{O}$ - enlarged view of left lateral edge showing longitudinal lines on that side, $\times 1.7$. 
This species is referred to Dorsolinevitus owing to the presence of longitudinal elements of sculpture on the shell. The very fine nature of the longitudinal sculpture separates it from all other species of this genus, although the overall conch form is suggestive of D.? esthonus. Neither of these species is sufficiently well known for any further comparison.

\section{Dorsolinevitus sp. B}

Fig. 4B-E

1888 Hyolithus inaequistriatus Remelé: 670, pl. 28: Fig. 6 (pars).

1946 Hyolithus inaequistriatus Remelé. - Sinclair: 77 (pars).

Material: MB.Hy.10 (Fig. 4B-C) and probably MB.Hy.22 (Fig. 4D-E).

Locality and horizon: MB.Hy.10 from near Eberswalde, collected in 1882 from the "upper gray Orthoceratites limestone," which is the Folkeslunda Limestone (Middle Ordovician); MB.Hy.22 is from the Lasnamagi Stage $\mathrm{C}_{1} \mathrm{~b}$, Middle Ordovician, near Lake Hiddensee on the island of Rügen, collected on a geological excursion led by the Museum für Naturkunde in July, 1950.

Description: Apparent orthoconic conch having only slightly inflated venter, grading into tightly rounded lateral edges; dorsum low with broad, rounded median ridge having flanks adjacent to it slightly inflated that dip gently toward lateral edges; cross section inferred to be triangular; ligula apparently short with anterior edge flattened in central region and sides of ligula dipping gently; aperture with narrow and shallow lateral sinuses.

On the venter the outer layer of shell has longitudinal ribs of varying intensity with spaces of irregular width between them, and the second layer has similar, although less conspicuous corresponding markings; internal mold with low, widely spaced transverse rugae in apical region; shell of uniform thickness.

Discussion: The individual on which the above description is largely based, MB.Hy.10, is preserved mostly as an incomplete internal mold with some shell adhering to the venter. It is $41 \mathrm{~mm}$ long, and is 14 wide and about $9 \mathrm{~mm}$ high in the apertural region; the apical angle is $22^{\circ}$. The dorsum is weathered and even details of the internal mold cannot be precisely determined. Preservation of the venter is slightly better with some shell from two layers remaining in places. Size and preservation of the other specimens of this species is similar to that of MB.Hy.10.

These individuals are referred to Dorsolinevitus owing to the longitudinal markings on the venter, which somewhat resemble those of D.? esthonus. The latter species however has a much larger apical angle and it is unlikely that both belong to the same species, although assignment of both to Dorsolinevitus is reasonable. Formerly, MB.Hy.10 was regarded as part of the type lot of Hyolithus inae- quistriatus Remelé, 1888, although Holm (1893) recognized that $H$. inaequistriatus actually combined specimens of two distinct morphologies, which he later separated into Hyolithus crispatus (Boll, 1859) and H. cymbium Holm, 1893. The former species was recently used as the type of the genus Crispatella Malinky, 2002 which is distinguished by its crenulated longitudinal ribs in places, and the latter, referred to Stelterella Malinky, 2002, is characterized by a pentagonal cross section and ribs that subdivide the dorsum into regions of distinctly differing slopes.

MB.Hy.10 possesses longitudinal sculpture that resembles that of both D.? esthonus and Dorsolinevitus $\mathrm{sp}$. A. The smaller apical angle separates Dorsolinevitus $\mathrm{sp}$. A from D.? esthonus, and the ornament of Dorsolinevitus sp. A separates it from all other species of that genus.

A specimen of similar conch proportion (MB.Hy.22) is tentatively assigned to this species due to similarities in proportions of the dorsum, in apical angle and in ornament to MB.Hy.10. This individual has the dorsum embedded in matrix and the apertural region is missing. It is $44 \mathrm{~mm}$ long and has a width at the apertural edge of about $17 \mathrm{~mm}$; the apical angle is $24^{\circ}$. Without question a second layer of shell is present, but markings if any are impossible to discern.

Family Hyolithidae Syssoiev, 1958

\section{Hyolithes Eichwald, 1840}

Type species: Hyolithes acutus Eichwald, 1840.

Included species: Hyolithes latus Eichwald, 1860, H. costulatus Barrande, 1867, H. bicostatus Novák, 1891, H. incurvatus Novák, 1891, H. bisulcatus Holm, 1893, H. concinnus Holm, 1893 and H. innotatus Holm, 1893, H. burgessi Malinky, 2003a, H. gerhardi Malinky, 2003a.

\section{Hyolithes acutus Eichwald, 1840 (emended)}

Figs $4 \mathrm{~L}-\mathrm{O}, 5 \mathrm{~A}-\mathrm{I}$

1840 Hyolithes acutus Eichwald: 97.

1860 Hyolithes acutus. - Eichwald: 1045, pl. 40: Figs 14a-c (non pl. 40: Figs 13a-c).

1861 Hyolithes acutus. - Eichwald: 300, pl. 19: Figs 14a-c (non pl. 19: Figs 13a-c).

1876 Hyolithes acutus. - Roemer, pl. 5: Figs 11a-d.

1885 Hyolithes acutus. - Roemer, pl. 2: Fig. 10.

1889 Hyolithes acutus. - Koken: 79, pl. 8: Figs 2, 3, 3a-c.

$1889 \mathrm{c}$ Hyolithes acutus. - Remelé: 767, pl. 30: Figs 1-5.

1893 Hyolithes acutus. - Holm: 99, pl. 2: Figs 29-36, pl. 6: Fig. 23.

1946 Hyolithes acutus. - Sinclair: 73.

1971 Hyolithes acutus. - Neben \& Krueger, pl. 20: Figs 13-15.

Lectotype: PSU 1/909 (figured by Eichwald 1860, pl. 40: Figs $14 a-c=$ Malinky 2006, fig. 4A-C).

Type locality and horizon: From either the Aseri or Väo Formation, Aseri or Lasnamägi Stage (Middle Ordovi- 
cian), locality uncertain, possibly from near Tallin, or Saaremõisa or the island of Osmussaar, Estonia.

Material: MB.Hy.3 (Koken 1889, pl. 8: Fig. 3 equals Figs 4L-O, 5A herein); MB.Hy. 5 (Koken 1889, pl. 8, fig. 2 equals Fig. 5E-F herein); MB.Hy.15 (Remelé 1889c, pl.30, figs $3 \mathrm{a}-\mathrm{b}$ equals Fig. 5B-D herein); MB.Hy.18; MB.Hy.19.2 (Fig. 5I); MB.Hy.21; MB.Hy.23; MB.Hy.25 (Fig. 5G-H); MB.Hy.38.1 - 38.2; MB.Hy.39a-b.

Localities and horizons: MB.Hy.3 from near the city of Neustrelitz in Mecklenburg-Vorpommern; MB.Hy.18 and MB.Hy.21 from near Lake Hiddensee on the island of Rügen along the north German Baltic coast; for MB.Hy.15 the locality is illegible on the label although Remelé (1889c, p. 767) stated that it was collected by P. Krause; near the town of Lebbin on the island of Wollin at what Remelé called locality 106 in his 1885 catalog of localities; MB.Hy.19.2 and MB.Hy.38.1-38.2 from Bydgoszcz, Poland; MB.Hy.23 from an unspecified locality in the state of Brandenburg; MB.Hy.25 from an unspecified locality near Berlin; all occur in the "upper gray Orthoceratite limestone" equals Folkeslunda Limestone, Lasnamägi Stage $\mathrm{C}_{1 \mathrm{~b}}$, Middle Ordovician. MB.Hy.39a-b from the Ordovician of "Velten b. Berlin"; MB.Hy.5 from near Tallinn, Estonia in the "Echinosphaerites" limestone equals Furudal Limestone, Uhaku Stage $C_{1 c}$ (Middle Ordovician).

Diagnosis: Hyolithes having small apical angle and therefore narrow, gently tapering conch; dorsum broad with poorly defined median ridge; shell on dorsum with fine longitudinal lines in central region and two slightly coarser longitudinal lines near each lateral edge on dorsum.

Description: Cyrtoconic conch having pronounced apical curvature toward dorsum; venter slightly inflated, grading into broadly rounded lateral margins which in turn pass into dorsal flanks that are only slightly inflated; flanks meet to produce a low, broadly rounded median dorsal ridge; exceedingly fine lateral furrows are present next to the first, dorsal-most longitudinal line; the cross section is lenticular with the dorsum being only slightly more inflated than the venter. The ligula is short and broadly rounded at the anterior edge with sides dipping gently toward the aperture; the dorsal rim is orthogonal and the lateral sinuses are shallow to nearly non-existent.

Shell on venter covered with very fine transverse growth lines of equal intensity whereas on dorsum there are four prominent longitudinal lines near each edge and nearly 20 slightly finer lines in middle of dorsum; the latter lines gradually become finer and some apparently disappear in apical region. Superimposed on these are wrinkly looking transverse ribs which may be discontinuous, bifurcate and even disappear in places.

Discussion: This genus was founded upon two specimens from the Middle Ordovician of Estonia by Eichwald (1840). Both are featureless, nondescript internal molds which lack any traces of shell (Malinky 2006). The poor preservation thereby allowed this generic concept to progressively expand to eventually incorporate any shell with a triangular cross section, this despite two fine re-descriptions of this species in the late $19^{\text {th }}$ century (Koken 1889; Holm 1893). Koken (1889) provided the best description of the species to date using material from the Geschiebe that was much better preserved than Eichwald's specimens. He illustrated several layers of shell but those layers are not, or perhaps are no longer, present on MB.Hy.3. He was followed shortly by Holm (1893) who also described and illustrated specimens of this species having more than one layer of shell. The description above is based largely on MB.Hy.3, which is Koken's specimen. That individual is generally well preserved though lacking the aperture. It is $65 \mathrm{~mm}$ long and is $19 \mathrm{~mm}$ wide and $12 \mathrm{~mm}$ high at the apertural end; the apical angle is $19^{\circ}$. The shell seems to have been thoroughly recrystallized or even replaced by blocky calcite spar, as the evidence for three layers seen in other specimens (Holm 1893) is lacking here. Based on those other specimens, it is the outermost layer of shell that is preserved here. The other layers possess markings dissimilar to the outermost, and an exfoliated specimen could easily be confused for a different species, as was the case with the three hyolith species of Boll (1859; see Holm 1893). The morphology of the conchs and second shell layer of the Geschiebe specimens supports the revision of that taxon presented by Malinky (2006) based on topotypic material from near Tallinn, Estonia. However, Hyolithes acutus is now known to possess an outer layer of shell having the longitudinal ornament described above. Formerly, it remained unclear whether Koken's (1889) and Holm's (1893) specimens belonged to this species, or represented another species of Hyolithes until topotype material was examined.

This species is the largest known to date for this genus, and it is also the one that possesses the greatest degree of apical curvature. The Geschiebe specimens suggest that there is some variation in degree of apical curvature, with MB.Hy.15 (Fig. 5D) having the greatest amount of any individual of H. acutus, or of any hyolith species in general. The intensity of the transverse lines seems to be more pronounced on MB.Hy.21 than on any other individual, and MB.Hy.15 has coarser longitudinal lines near the lateral edges than the other individual.

This species is easily separated from all others assigned to this genus by the longitudinal lines on the dorsum, details of the lateral furrows and apical angle. Hyolithes latus Eichwald, 1860, H. costulatus Barrande, 1867, H. bicostatus Novák, 1891 and H. incurvatus Novák, 1891 all lack longitudinal lines or other longitudinal sculpture. Hyolithus concinnus Holm, 1893, H. innotatus Holm, 1893 and H. burgessi Malinky, 2003a have narrow conchs owing to their small apical angles, and the latter species likewise possesses pervasive longitudinal ribs on the venter. Hyolithes bisulcatus Holm, 1893 has much deeper lateral furrows than does H.acutus, and H. gerhardi Malinky, 2003a has a higher dorsum and coarse, transverse dorsal ribs. 
The species appears to be restricted to Baltica with specific reports from Estonia, Sweden and Norway (Holm 1893) in addition to from the Geschiebe of Germany and Poland.

\section{Hyolithes latus? Eichwald, 1860}

Fig. $5 \mathrm{~J}-\mathrm{R}$

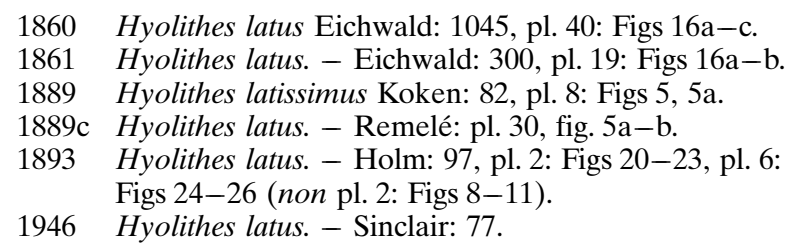

Holotype: PSU 1/908 (figured by Eichwald 1860, pl. 40: Figs 16a $-\mathrm{c}=$ Malinky 2006, Fig 6I-J).

Type locality and horizon: Osmussaar, Estonia, possibly from the Väo Formation, Lasnamägi or Uhaku stages (Middle Ordovician).

Material: MB.Hy.16 (Remelé 1889c, pl.30, fig. 4a= Fig. 5K-L herein); MB.Hy.17 (Remelé 1889c, pl. 30, fig. 5a-b $=$ Fig. 5M-N herein); MB.Hy.26; MB.Hy.41 (Fig. 5O-R); possibly MB.Hy.4 (Fig. 5J).

Localities and horizons: MB.Hy.4 collected on Rügen near lake Hiddensee as part of the geological excursion by the Naturkunde Museum in July, 1950, and MB.Hy.16a-b from near the city of Neustrelitz in Mecklenburg-Vorpommern, both from the "upper gray Orthoceratite limestone" equals Folkeslunda Limestone, Lasnamägi Stage $\mathrm{C}_{1 \mathrm{~b}}$, Middle Ordovician.; MB.Hy.17 from "dark gray Orthoceratites limestone" thus the exact level is uncertain, from near Gransee; MB.Hy.26 from Gemmersdorf, level uncertain; MB.Hy.41, from level $\mathrm{B}_{3} \mathrm{a}$, at Jagojasal, collected by Koken, Kunda Stage, Middle Ordovician.

Description: Seemingly orthoconic conch with rounded inflated venter, grading into tightly rounded lateral edges, which in turn pass into dorsum with low, broad median ridge that is inflated to nearly the same degree as the venter; shallow lateral furrows occur on the internal mold of the dorsum near the lateral edges; the cross section has a lenticular shape. Aperture appears to be oxygonal with deep, well defined lateral sinuses; the ligula is short but distinctly rounded at the anterior edge with sides that dip away gently from the edge. Shell on dorsum with steep-sided transverse ribs that have spaces between them equal to the width of two ribs; internal mold of venter has low, widely and irregularly spaced transverse rugae.

Discussion: This species is known in the Geschiebe only from fragmentary specimens that possess varying amounts of shell in places on the internal mold. The foregoing description is based largely on MB.Hy.16a (Fig. 5K-L). It is $52 \mathrm{~mm}$ long and has an apical angle of $13^{\circ}$, but lacks both apertural and apical terminations; preservation of all other individuals is similar. Details of the shell are well enough preserved on MB.Hy.16a so that the nature of the aperture can be inferred, and the lateral furrows are visible near the dorso-ventral transition (Fig. 5K).

These individuals are referred to Hyolithes due to the lateral furrows on the dorsum. This species is assigned with question to Hyolithes latus Eichwald, 1860 due to the higher dorsum than that of $H$. acutus, as well as the apparent orthoconic conch and transverse sculpture present only on the dorsum. These are diagnostic traits of Hyolithes latus (see Malinky 2006). Differences between this species and the others under Hyolithes were given above under H. acutus.

\section{Family uncertain 1}

\section{Genus Nevadotheca Malinky, 1988}

Type species: Hyolithes whitei Resser, 1938.

Included species. N. tenuistriata Linnarsson, 1871, N. socialis Linnarsson, 1871, N. excellens, Billings, 1872a, N. princeps Billings, 1872b, N.? billingsi Walcott, 1886, N.? arenophilus Holm, 1893, N.? subcostata Wallerius, 1895, N. heckeli Malinky, 1989.

\section{Nevadotheca? sp.}

Fig. $6 \mathrm{~J}-\mathrm{K}$

?1979 Orthotheca degeeri. - Neben \& Krueger, pl. 112: Fig. 3.)

Mate rial: MB.Hy.83a (Fig. 6J); MB.Hy.83b (Fig. 6K), Middle Cambrian, from a locality given as "Vierraden bei Schwedt" on the label.

Description: Seemingly orthoconic conch with small apical and therefore narrow, tapering appearance; venter only slightly inflated and rounded in middle; ligula short with rounded anterior edge and gently sloping slides; exterior covered with widely and irregularly spaced rugae of varying degrees of coarseness, and in some places spaces between rugae appear deep enough to be considered constrictions.

Discussion: Two individuals in the same boulder are assigned with question to Nevadotheca Malinky, 1988 because they match well the ventral morphology of Nevadotheca arenophilus (Linnarsson, 1871) from the Middle Cambrian of Sweden. The Geschiebe specimens are casts in sandstone with only the venter exposed, therefore confident assignment to genus or species is impossible.

Detailed comparison to the other species of Nevadotheca listed above is precluded by the incomplete preservation of the Geschiebe individual. That individual bears greatest resemblance in conch proportions to Nevadotheca? arenophilus (Holm, 1893), with resemblance further supported by preservation: both Nevadotheca sp. and N. arenophilus occur as molds and casts in sandstone and both are about the same age. Malinky \& Berg-Madsen (1999) judged 
A

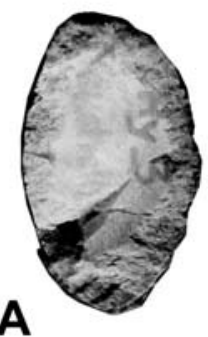

B
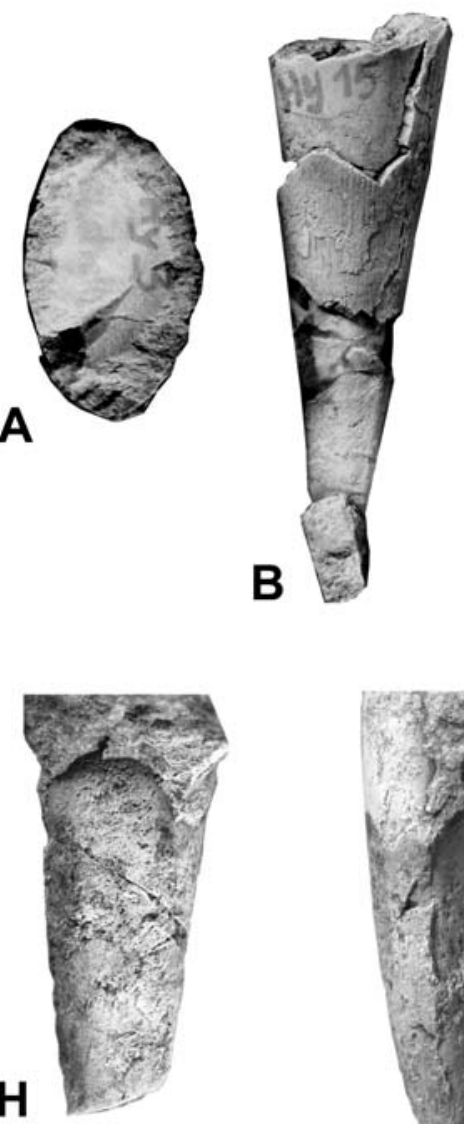

M

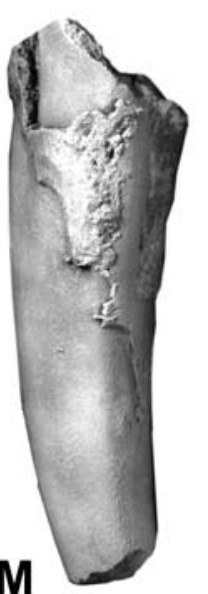

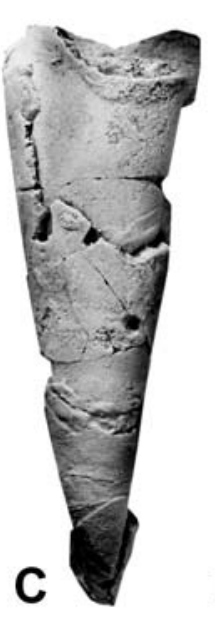

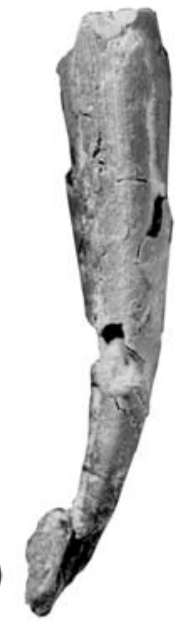

E
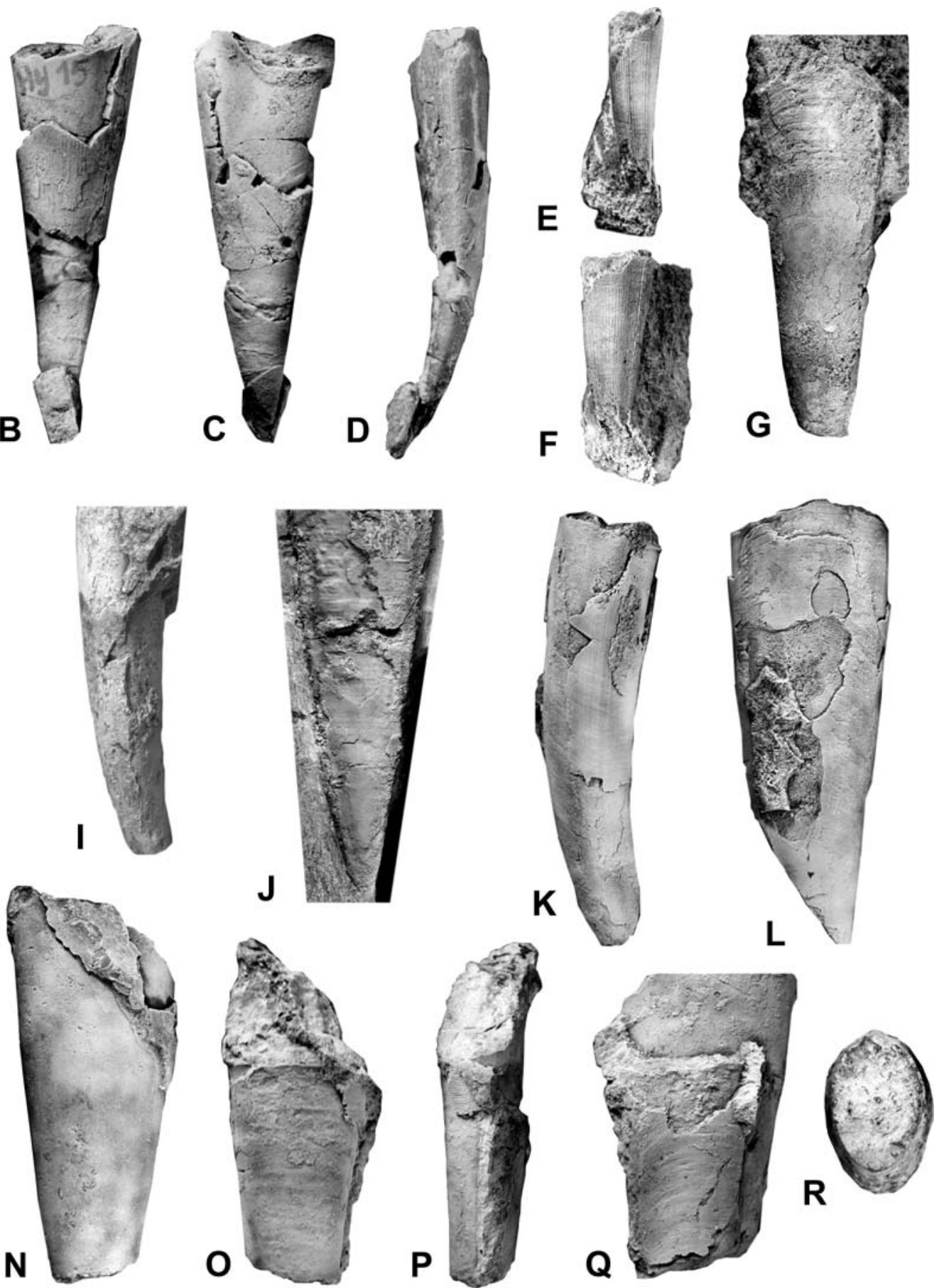

Fig. 5. Hyolithes acutus Eichwald, 1840 from Neustrelitz, Germany. MB.Hy.3, A - cross-section, $\times$ 1.1. Hyolithes acutus Eichwald, 1840 from near Lebbin on the island of Wollin, Germany. MB.Hy.15, B - dorsum, C - venter, D - right lateral view, $\times 2$. Hyolithes acutus Eichwald, 1840 from near Tallinn, Estonia. MB.Hy.5, E - left lateral view, $\mathbf{F}-$ dorsum of apical region, $\times 2.5$. Hyolithes acutus Eichwald, 1840 from near Berlin. MB.Hy.25, G - venter and $\mathbf{H}-$ dorsum, $\times 1$. Hyolithes acutus Eichwald, 1840 from from near Bydgoszcz, Poland. MB.Hy.19.2, I - right lateral view, $\times 1$. Hyolithes latus? Eichwald, 1860 from near lake Hiddensee on the island of Rügen, Germany. MB.Hy.4, J - dorsum, $\times 0.75$. MB.Hy.16a from Neustrelitz, Germany. K - venter, L - enlarged left lateral view, $\times 1.2$. Hyolithes latus? Eichwald, 1860 from near Gransee, Germany. MB.Hy.17, M - left lateral view and $\mathbf{N}-$ venter, $\times 1$. Hyolithes latus? Eichwald, 1860 from a locality called Jagojasal by Koken (1889). MB.Hy.41, $\mathbf{O}$ - dorsum, $\mathbf{P}$ - right lateral view, $\mathbf{Q}-$ venter, $\mathbf{R}-$ cross section of apical region, $\times 2$.

Nevadotheca? arenophilus (Holm, 1893) to be an unrecognizable species owing to incomplete preservation. The occurrences of Nevadotheca sp. and N. arenophilus (Holm, 1893) are reminiscent of hyolith occurrences in sandstone layers in the USA in the Upper Mississippi Valley region and in Wyom- ing, where specimens of species including Hyolithes gregarius Meek and Hayden, 1861 and H. primordialis (Hall, 1861) have been earlier recognized. These species were also judged to be unrecognizable (Malinky 1989) due to the paucity of preserved morphologic features. 

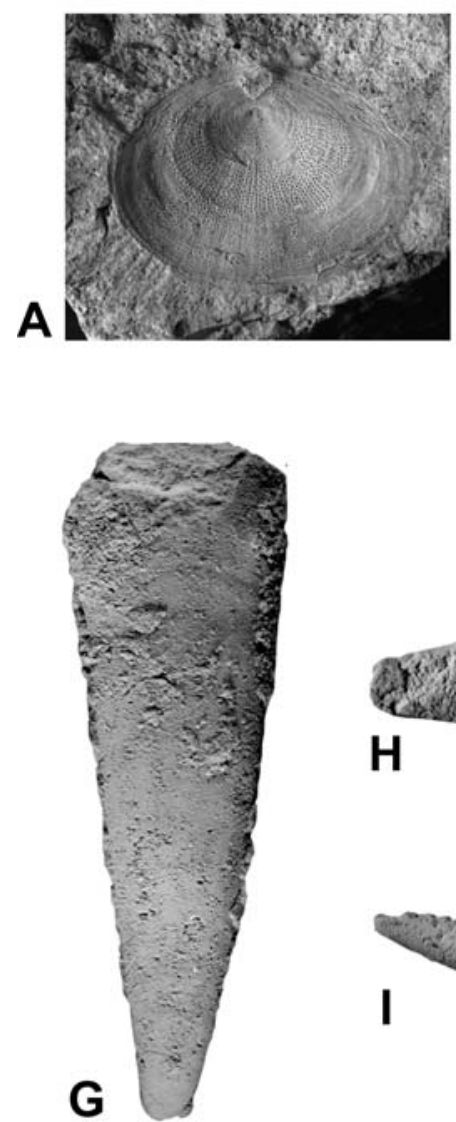

B
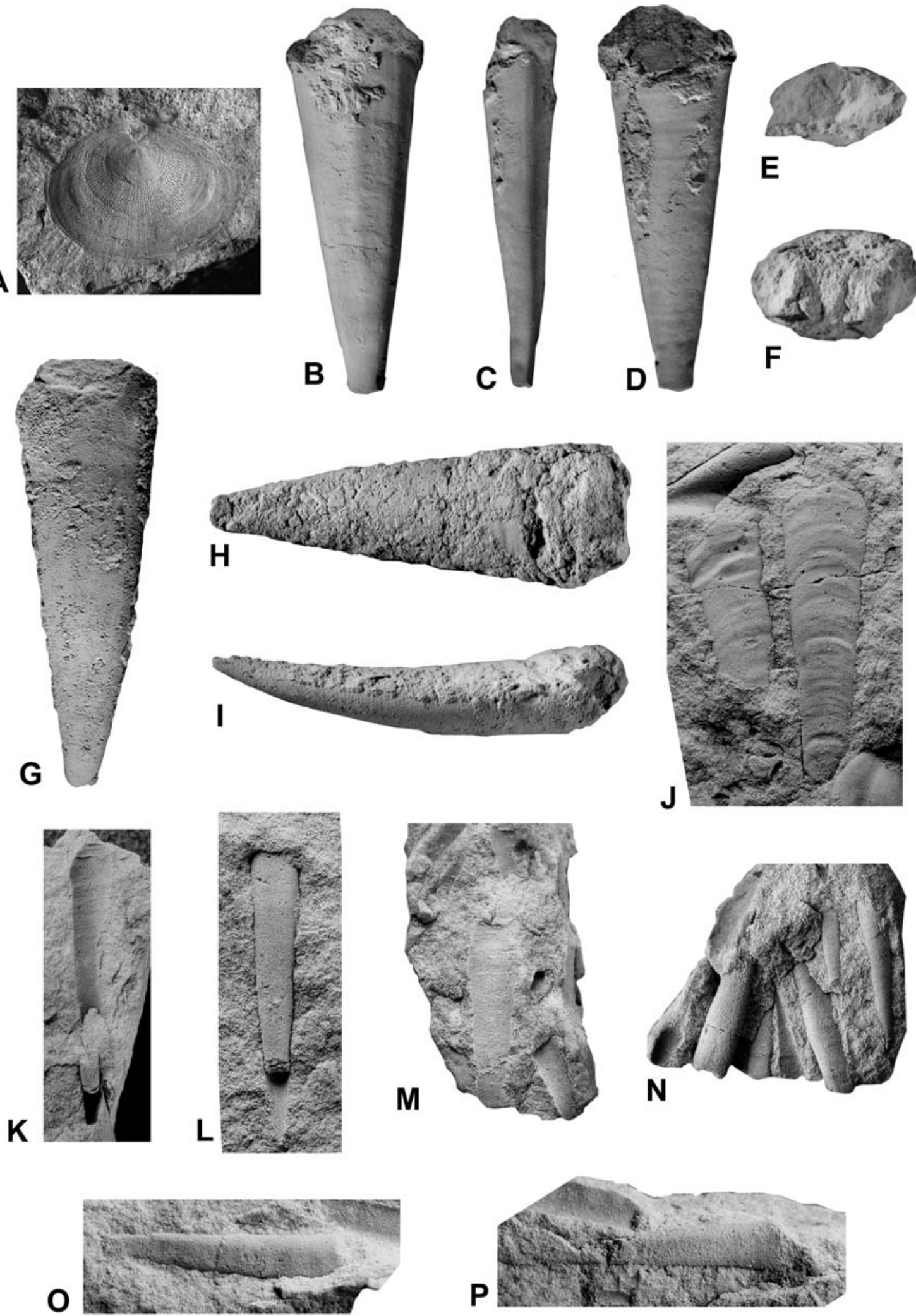

Fig 6. Operculum A, label illegible and locality unknown. MB.Hy.33, A - exterior view, $\times$ 1.4. "Hyolithes" vaginati (Quenstedt, 1852) from Žary, Poland. TU 1 here designated lectotype, B - venter, $\mathbf{C}$ - right lateral edge, D - dorsum, E - crosssection, $\times$ 1.8. "Hyolithes" vaginati (Quenstedt, 1852) from unspecified locality in state of Brandenburg. Germany. TU 2 paralectotype, $\mathbf{F}$ - cross-section, $\mathbf{G}$ - venter, $\mathbf{H}$ - dorsum and $\mathbf{I}$ - right lateral view, $\times$ 1.2. Nevadotheca? sp. from "Vierraden bei Schwedt," Germany. MB.Hy.83a, J - ventral view of two conchs, $\times 2$. Nevadotheca? sp. from "Vierraden bei Schwedt," Germany. MB.Hy.83b, K - external mold of conch with small portion of internal mold preserved in apical region, $\times 1.3$. Holmitheca? sp. from near Berlin, Germany. MB.Hy.74.1, L - internal mold of venter, $\times 1.1$. Holmitheca? sp. from Niederfinow, Germany. MB.Hy.90.1, M - impression of venter, $\times$ 1.5. Holmitheca? sp. from from Niederfinow, Germany. MB.Hy.90.2, $\mathbf{N}-$ oriented conchs in matrix, $\times 2$. Holmitheca? sp. from unknown locality. MB.Hy.86.2, $\mathbf{O}-$ ventral internal mold, $\times 1.6$. Holmitheca? sp. from unknown locality. MB.Hy.86.1, P - ventral internal mold, $\times 1.7$. 
Nevadotheca tenuistriata and N. excellens are much larger than the Geschiebe specimen, assuming that the Geschiebe individual is a normal-sized adult. Nevadotheca socialis has a much smaller apical angle and therefore narrow conch than does Nevadotheca? sp., and with $N$. heckeli the situation is the opposite, involving a much larger apical angle and therefore wider conch. Nevadotheca? subcostata (Wallerius, 1895) preserves shell fragments with external sculpture and cannot be compared further to Nevadotheca? sp. because the latter species lacks any traces of shell.

The Geschiebe hyoliths are associated with a specimen of Paradoxides thus the Middle Cambrian age of the specimen is firmly established.

\section{Family uncertain 2}

\section{Operculum A}

Fig. 6A

Material: MB.Hy.33 (Fig. 6A).

Locality and horizon: "Silurian diluvium", all other details on the label are illegible.

Description: Broad conical shield arched slightly in middle; rooflets easily distinguishable though narrow; cardinal shield small and lying nearly in same plane as conical shield; summit inferred to be small and knob-like; exterior surface covered with concentric, irregularly spaced rugae.

Discussion: This specimen is an impression of the exterior on a fine-grained sandstone or siltstone. It is $24 \mathrm{~mm}$ wide from one lateral edge to the other, and $17 \mathrm{~mm}$ high. The conch associated with it would have to have been quite large to accommodate this specimen, and the ligula would have to be rather short, given that the cardinal shield which extends to cover the ligula is itself small and resting in almost the same plane as the conical shield. The cross section of the conch would have an inflated triangular shape. Only specimens of Hyolithes acutus Eichwald, 1840 would be large enough to accommodate such an operculum but the cross section of that species is lenticular rather than triangular. Otherwise, no conch from the Geschiebe could be reasonable associated with this operculum.

\section{Hyolithida incertae sedis}

\author{
“Hyolithes" vaginati (Quenstedt, 1852) \\ Fig. 6B-I \\ 1852 Pugiunculus vaginati Quenstedt: 398. \\ 1867 Pugiunculus vaginati. - Quenstedt: 475, pl. 44: Fig. 35. \\ 1885a Pugiunculus vaginati. - Quenstedt: 610. \\ 1885b Pugiunculus vaginati. - Quenstedt, pl. 48, Fig. 23 \\ 1889 non Hyolithes vaginati. - Koken: 80-81, pl. 8: Figs 6, \\ $6 \mathrm{a}-\mathrm{b}$. \\ 1946 Hyolithes vaginati. - Sinclair: 81.
}

Lect otype: TU 1 (Fig. 6B-E), here designated.

Material: Two paralectotypes TU 2 (Fig. 6 F-I); MB.Hy.30. Type locality and horizon: Lectotype from Žary, in southwestern Poland, horizon uncertain, Middle Ordovician.

Material: Paralectotype TU 2 and MB.Hy.30 from an unknown locality or localities in the state of Brandenburg, Germany; ?Middle Ordovician.

Description: Nearly orthoconic conch with slight dorsal curvature in apical region only; conch has small apical angle creating a gently tapering appearance; venter has pronounced ridge in middle region, mimicking ridges ordinarily seen on the dorsum of hyolithids, and thus the cross-section is nearly elliptical but with a pronounced keel in the middle of both dorsal and ventral sides. The ligula was apparently short with gently dipping sides and the aperture was seemingly orthogonal. Dorsal internal mold has widely and irregularly spaced transverse rugae, whereas similar rugae on venter follow the edges of the aperture; otherwise the internal mold is smooth. The shell becomes thinner in the apertural region as evidenced by a swelling of the internal mold in that area.

Discussion: This species was founded on two incompletely preserved internal molds, and TU1 is here designated lectotype. That individual is about $35 \mathrm{~mm}$ long, and has an apertural width and height of about $12 \mathrm{~mm}$ and $8 \mathrm{~mm}$ respectively; the apical angle is $16^{\circ}$. A few pieces of weathered shell adhere in the apertural region on both dorsal and ventral sides, but no details of the exterior are preserved. A second specimen included under this species by Quenstedt (1852) is about $50 \mathrm{~mm}$ long and is more dorsally curved; whether it is an ecophenotypic variant of the same species is impossible to judge because its preservation is equally poor. No useful purpose is served by formally removing it from this species and describing it as a separate taxon.

Quenstedt's (1852) description of this species mentioned that one side of the conch is convex and the other concave; a thin shell was also discussed, and the presence of the ligula noted. "Fine concentric stripes" are also said to have been present, although none of these features are discernible on the two existing specimens of this species. Quenstedt (1852) never specified how many specimens were available to him, and perhaps any better preserved individuals are now lost.

The original generic designation of this species, Pugiunculus, has been the subject of recent discussion. Malinky \& Lichtenberger (2005) revised three species of this genus established by Sandberger \& Sandberger (1854) from the Devonian Rhenish Mountains, and in so doing gave a history of the use of this name. That name came to be regarded as a synonym of Hyolithes Eichwald, 1840 by Barrande (1867), and Quenstedt (1885a, 1885b) appears to have been the last worker to use Pugiunculus as a generic designation for a hyolith. 
Despite the highly generalized description and paucity of morphologic detail, Koken (1889) attempted to unite this species with Hyolithes latus Eichwald, 1860 and H. inaequistriatus Remelé, 1888, both of which were mentioned earlier in this report. In reality, "Hyolithes" vaginatus cannot be compared in any meaningful fashion with any other hyolith species. A specimen collected by L. von Buch in the mid-1 $19^{\text {th }}$ century and identified as this species on a label handwritten by Quenstedt (MB.Hy.30) is an internal mold which likewise cannot be assigned with any confidence to genus or species. This species' name should be restricted solely to the type material until such time as better preserved specimens are discovered and the species then can be established on a sound morphologic basis.

Order Orthothecida Marek, 1966

\section{Holmitheca Syssoiev, 1968}

Type species: Holmitheca obvia Syssoiev, 1968.

Included species: H. ulterior (Syssoiev, 1968); H. zhuravleva Syssoiev, 1972; H. quadricostata (Shaler \& Foerste, 1888).

\section{Holmitheca? sp.}

Fig. 6L-P

1979 Orthotheca degeeri. - Neben \& Krueger, pl. 111: Fig. 6, pl. 112: Fig. 4.

Material: MB.Hy.74.1-2 (Fig. 6L); MB.Hy.85a-b; MB.Hy.86.1 (Fig. 6P); MB.Hy.86.2 (Fig, 6O), MB.Hy.90.1-2 (Fig. 6M-N).

Localities and horizons: MB.Hy.74.1-2 is from the Lower Cambrian green sandstone, Berlin, collected by Meyer, 1951; MB.Hy.90.1-2 is from a Lower Cambrian boulder found in Niederfinow; MB.Hy.85.1-2 (part/counterpart) is from the Lower Cambrian near Lake Hiddensee on Rügen; the locality and horizon of MB.Hy.86.1-2 are unknown.

Description: Elongate, orthoconic conch with small apical angle and therefore gently tapering appearance; venter with very shallow longitudinal median concavity which appears flat in central region; sub-rounded longitudinal ridges adjacent to the concavity are very low, and apparently grade into rounded and inflated lateral edges. Dorsum very broadly rounded, and cross section inferred to be a weakly developed kidney-shape. Shell on the dorsum with transverse ribs near apertural end and seemingly smooth elsewhere.

Discussion: This taxon is known from molds and casts in several pieces of sandstone; all individuals are approximately $25 \mathrm{~mm}$ long with apical angles of approximately $8^{\circ}$. Similarities in apical angle and nature of the venter to each other suggest that all specimens could reasonably be accommodated under the same taxon. They are assigned with question to Holmitheca Syssoiev, 1968 because they are similar in conch proportions and nature of the ventral concavity to that genus. Assignment to species awaits the discovery of better preserved specimens.

Identification to species is more problematic because the Geschiebe specimens lack any traces of shell, although limited comparison involving overall conch proportions is possible. The ventral concavity of Holmitheca obvia Syssoiev, 1968 and H. ulterior (Syssoiev, 1968) is far deeper than that of the Geschiebe specimen; on H. zhuravleva Syssoiev, 1972 not only is the concavity deeper but also much narrower with prominent transverse ribs and constrictions also present on the venter. Holmitheca quadricostata (Shaler \& Foerste, 1888) possesses a deep ventral concavity and a median ridge on the dorsum which is clearly lacking on Holmitheca? sp.

Class ?Gastropoda Cuvier, 1797

\section{Ceratotheca Novák, 1891}

Type species: Ceratotheca adunca (Barrande, 1867).

Included species: C. barrandei Novák, 1891; C. oxygona Novák, 1891; C. ultima Novák, 1891; C. unguiformis Novák, 1891.

\section{Ceratotheca? erratica (Koken, 1889)}

Fig. 7A-C

1889 Hyolithes erraticus Koken: 81, pl. 8: Fig. 3.

1946 Hyolithes erraticus. - Sinclair: 76.

1973 Ceratotheca? erratica. - Neben \& Krueger, pl. 104: Figs 32-34.

Material: Holotype by monotypy MB.Hy.6 (Fig. 7A-C).

Locality and horizon: From a glacial boulder in the Kreuzberg section of Berlin; the boulder was derived from the Silurian graptolite rocks of Ludlowian/Wenlockian age, from southern Sweden.

Description: Disjunct gastropod? with basal whorl surface relatively flat with rounded to near angular lateral margins; flanks of upper surface
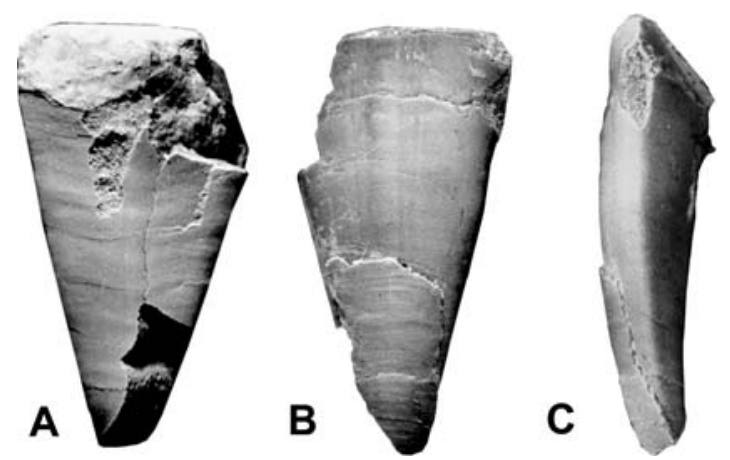

Fig. 7. Ceratotheca? erratica (Koken, 1889) from the Kreuzberg section of Berlin, Germany. Holotype MB.Hy.6, A - "dorsum", B - "venter," C - "left lateral view," $\times 4$. 
generally compressed and appear nearly flattened with only slight rounding in middle portion; early growth stages unknown, mature individuals probably completing less than onefourth whorl; shell essentially lying in one plane with slight logarithmic curvature near apical end; shell with fine, seemingly transverse lines; cross section triangular.

Discussion: This species is known only from the holotype, which is $11 \mathrm{~mm}$ in long, and has an apertural "width" and "height" of $6 \mathrm{~mm}$ and approximately $3 \mathrm{~mm}$; the apical angle is inferred to be $30^{\circ}$. Preservation is incomplete; it is an internal mold with no traces of shell remaining, although enough detail is retained to understand Koken's (1889) motivation in referring this species to Hyolithes Eichwald, 1840. The ruling criteria in assigning it to that genus were undoubtedly the seemingly flat 'venter' and inflated 'dorsum' which gave rise to a triangular cross section. The specimen bears greater similarity to the problematic Ceratotheca Novák, 1891 from the Silurian and Devonian of the Barrandian region. Novák (1891) regarded that form as a hyolith, though Marek \& Yochelson (1976) reinterpreted it as a gastropod, an attribution followed herein. They regarded it as such chiefly because of the slight logarithmic curvature of the shell, a feature never seen among authentic hyoliths. This species differs from all other species of Ceratotheca Novák, 1891 by its relatively uncoiled conch whereas all others complete half a whorl or more.

Syssoiev (1968) accepted hyolith affinity for Ceratotheca Novák, 1891 and raised that taxon to ordinal rank; later he subdivided Ceratotheca into several new genera (Syssoiev 1970). Thus far the only unequivocal records of Ceratotheca are from the Silurian and Devonian of the Barrandian region, its type area; specimens of this genus reported by Reed (1909) from the Ordovician of Scotland were reinterpreted as gastropods (Malinky 2003b). Syssoiev (1968) included a hyolithid species of Hall (1876) from New York under that genus, thereby greatly expanding its geographic range. Hall's (1876) species has since been recognized as a fragment of sandstone of inorganic origin (Malinky et al. 1987). If the occurrence of Cerathotheca erratica (Koken, 1889) noted herein is authentic, then the geographic range of the taxon is extended into Baltica where the boulders bearing these fossils originated. The species Cerathotheca oxygona (Novák, 1891, see Neben \& Krueger 1971, pl.104: Figs 35-40) was also reported from the Geschiebe, but those specimens cannot be located at present.

\section{Acknowledgments}

I am grateful to the late Dr. H. Jaeger, Museum für Naturkunde der Humboldt Universität zu Berlin for welcoming me to the museum and allowing me access to type specimens, and to D. Korn and H. Scholz for serving as my host of my later visits; D. Korn likewise skillfully corrected all the technical errors in the manuscript and figures, and provided much encouragement during the course of this project. B. Kröger of the Naturkunde Museum, and A. Nützel, Friedrich-Alexander-Universität Erlangen-Nuremberg, reviewed the manuscript and provided many useful comments and suggestions. M. Lichtenberger, Geologisch-Paläontologisches Institut der Ruprecht-Karls-Universität, Heidelberg provided the translation of the abstract into German. J. Březina, University of Maryland University College, assisted in translating German literature, and in many other ways in the preparation of this manuscript. C. Akerman and L. Karis both of the Swedish Geological Survey, generously permitted access to Holm's collections of hyoliths, and J. Wendt, Eberhard-Karls-Universität Tübingen provided photographs of Quenstedt's specimens. Thanks are also extended to J. Arden, P. Phillips, M. Zwink, E. Stelter and L. Court, all of the University of Maryland University College, for their unwavering logistical support of this and many other projects during my time with the university.

\section{References}

Barrande, J. 1867. Systeme silurien de la Bohême. Ordres des Pteropodes. 3, 1-179. Published by the author, Prague and Paris.

Bassler, E. L. 1911. The Early Paleozoic Bryozoa of the Baltic Provinces. United States National Museum, Bulletin 77: $1-382$.

Berg-Madsen, V. \& Malinky, J. M. 1999. A revision of Holm's Late Mid and Middle Cambrian hyoliths of Sweden. - Palaeontology 42: 841-885.

Billings, E. 1872a. On some fossils from the Primordial rocks of Newfoundland. - The Canadian Naturalist 6: 465-479.

- 1872b. On some new species of Palaeozoic fossils. The Canadian Naturalist, new series 6: 213-222.

Boll, E. 1859. Die Pteropoden unserer silurischen Gerölle. Archiv des Vereins der Freunde der Naturgeschichte in Mecklenburg, Jahr 13, section 7, part A, chapter 2: 161164.

Carter, J. G. 1989. Evolutionary significance of shell microstructure in the Palaeotaxodonta, Pteriomorpha and Isofilibranchia (Bivalvia: Mollusca). - In Carter, J. G. (ed.). Skeletal Biomineralization. Patterns, Processes and Evolutionary Trends, 1: 136-296. Van Nostrand Reinhold, New York.

Cuvier, G. 1797. Tableaus élémentaire de l'histoire naturelle des animaux. 710 pp., Paris.

Dronov, A. \& Holmer, L. E. 1999. Depositional sequences in the Ordovician of Baltoscandia. - Acta Universitatis Carolinae, Geologica 43: 133-136.

Ebbestad, J. O. R. \& Peel, J. S. 1997. Attempted predation and shell repair in Middle and Upper Ordovician gastropods from Sweden. - Journal of Paleontology 71: 10071019.

Eichwald, K. E. von. 1840. Über das silurische Schichtensystem in Esthland. - Zeitschrift für Natur- und Heilkunde der königlich Medicinisch-chirurgischen Akademie St. Petersburg, 1/2: 1-210.

- 1860. Lethaea Rossica ou Paleontologie de la Russie. D. E. Schweizerbart, 1: 1-1657.

- 1861. Paleontologiya Rossii. Drevniy Period. II. Fauna grauvakkovoy, gornoizvestkovoy i miedistoslancevatoy formaciy Rossii. [Paleontology of Russia. Ancient Period. II. Fauna of the graywacke, upper limestone and copperbearing shale formations of Russia]. 521 pp., issued by Ya. Ionson, in the typography of R. Golike, St. Petersburg.

Fisher, D. W. 1962. Small conoidal shells of uncertain affinities. - In Moore, R. C. (ed.). Treatise on Invertebrate Paleontology: W98-W143. Geological Society of America and University of Kansas Press, Lawrence. 
Hall, J. 1861. Report of the Superintendent on the progress of work, January 1, 1861. Geological Survey of Wisconsin, $52 \mathrm{pp}$.

- 1876. Illustrations of Devonian fossils: Gasteropoda, Pteropoda, Cephalopoda, Crustacea and Corals of the Upper Helderberg, Hamilton and Chemung Groups. 39 pls (no text), Weed, Parsons and Company, Albany.

Heidrich, H. 1967. Bestimmungstafeln für Hyolithen. - Geschiebesammler 2: 27-34

Henderson, R. A., Kennedy, W. J. \& Cobban, W. A. 2002. Perspectives of ammonite paleobiology from shell abnormalities in the genus Baculites. - Lethaia 35: 215-230.

Holm, G. 1893. Sveriges Kambrisk-Siluriska Hyolithidae och Conulariidae. - Serviges Geologiska Undersökning, Afhandlinger och uppsatser, Series C 112: 1-172.

Hucke, K. \& Voight, E. 1967. Einführung in die Geschiebeforschung (Sedimentärgeschiebe). 132 pp., Nederlandse Geologische Vereniging, Oldenzaal.

Jannusson, V. 1960. The Viruan (Middle Ordovician) of the Siljan District. - Bulletin of the Geological Institutions of Uppsala 38: 207-288.

- 1963. Lower and Middle Viruan (Middle Ordovician) of the Siljan District. - Bulletin of the Geological Institutions of Uppsala 42: $1-40$.

Jannusson, V. \& Mutvei, H. 1951. Ein Profil durch den Vaginatum-Kalkstein im Siljan-Gebiet, Dalarna. - Geologiska Föreningens i Stockholm Förhandlingar 73: 630-636.

- 1953. Stratigraphie und Lithologie der unterordovizischen Platyurus-Stufe im Silja-Gebiet, Dalarna. - Bulletin of the Geological Institutions of Uppsala 35: 1-34.

Koken, E. F. R. K. 1889. Die Hyolithen der silurische Geschiebe. - Zeitschrift der Deutschen Geologischen Gesellschaft 1889: 79-82.

- 1896. Die Leitfossilien. Ein Handbuch für den Unterricht und das Bestimmen von Versteinerungen. 848 pp., C. H. Tauchnitz, Leipzig.

Kröger, B. 2004. Revision of Middle Ordovician orthoceratacean nautiloids from Baltoscandia. - Acta Palaeontologica Polonica 49: 57-74.

Larsson, K. 1973. The Lower Viruan in the autochthonous Ordovician sequence in Jämtland. - Serviges Geologiska Undersökning Series C 683: $1-82$.

Linnarsson, J. G. O. 1871. Om några forsteningar från Sveriges och Norges "Primordialzon". - Öfversigt af Kungliga Vetenskaps-Akademiens Förhandlingar 6: 789-796.

Malinky, J. M. 1988. Early Paleozoic Hyolitha from North America; reexamination of Walcott's and Resser's type specimens. - Journal of Paleontology 62: 218-233.

- 1989a. New Early Paleozoic Hyolithida and Orthothecida (Hyolitha) from North America. - Journal of Paleontology 63: 302-319.

- 1990. Solenotheca, new Hyolitha (Mollusca) from the Ordovician of North America. - Proceedings of the Biological Society of Washington 103: 265-278.

- 2002. A revision of early to Mid Ordovician hyoliths from Sweden. - Palaeontology 45: 511-555.

- 2003a. New Middle and Late Ordovician hyoliths from Estonia. - Journal of Paleontology 77: 304-313.

- 2003b. Ordovician and Silurian hyoliths and gastropods reassigned from the Hyolitha from the Girvan district, Scotland. - Journal of Paleontology 77: 625-645.

- 2006. Revision of Hyolitha from the Ordovician of Estonia. - Paläontologische Zeitschrift 80: 88-106.

Malinky, J. M. \& Mapes, R. H. 1983. First occurrences of Hyolitha (Mollusca) in the Pennsylvanian of North America. - Journal of Paleontology 57: 347-353.

Malinky, J. M. \& Sixt, S. 1990. Early Mississippian Hyolitha from northern Iowa. - Palaeontology 33: 343-357.

Malinky, J. M. \& Berg-Madsen, V. B. 1999. A revision of Holm's Early and early Middle Cambrian hyoliths of Sweden. - Palaeontology 42: 25-65.

Malinky, J. M. \& Lichtenberger, M. 2005. Hyolitha and other problematica from the Rheinische Schiefergebirge (Lower Devonian), and their palaeobiological significance. -
Neues Jahrbuch für Mineralogie und Paläontologie 238: 79-106.

Malinky, J. M., Linsley, R. M. \& Yochelson, E. L. 1987. Taxonomic revision of Hyolitha from the Middle Paleozoic of North America. - Journal of Paleontology 61: 11731186.

Marek, L. 1963. New knowledge on the morphology of Hyolithes. - Sborník geologických věd, řada paleontologie 1: $53-72$.

- 1966. New hyolithid genera from the Ordovician of Bohemia. - Casopis národního muzea 135: 89-92.

- 1976. The distribution of the Mediterranean Ordovician Hyolitha. - In Bassett, M. G. (ed.). The Ordovician System: proceedings of a Palaeontological Association Symposium, Birmingham, September, 1974: 493-499. University of Wales Press and National Museum of Wales, Cardiff.

Marek, L. \& Galle, A. 1976. The tabulate coral Hyostragulum, an epizoan with bearing on hyolithid ecology and systematics. - Lethaia 9: 51-64.

Marek, L. \& Yochelson, E. L. 1976. Aspects of the biology of Hyolitha (Mollusca). - Lethaia 9: 65-81.

Meek, F. B. \& Hayden, F. V. 1861. Descriptions of new Lower Silurian (Primoridal), Jurassic, Cretaceous, and Tertiary Fossils, collected in Nebraska, by the exploring expedition under the command of Capt. W. F. Reynolds, U. S. Topographic Engineers; with some remarks on the rocks from which they were obtained. - Proceedings of the Philadelphia Academy of Natural Sciences 5: 415-447.

Neben, W. \& Krueger, H.-H. 1971. Fossilien ordovizischer Geschiebe. - Staringia 1, pls. 1-50 (plates only).

- 1973. Fossilien ordovizischer und silurischer Geschiebe. Staringia 2, pls. 51-109 (plates only).

- 1979. Fossilien kambrischer, ordovizischer und silurischer Geschiebe. - Staringia 5, pls. 110-164 (plates only).

Novák, O. 1891. Revision der palaeozoischen Hyolithiden Böhmens. - Abhandlungen der mathematisch-naturwisschenschaftlichen Classe der böhmischen Gesellschaft der Wissenschaften, ser. 7 4: 1-48.

Patrunky, H. 1928. Pteropoden, Gastropoden und Brachiopoden aus Geschieben der silurischen Orthocerenkalke. Zeitschrift für Geschiebeforschung 14: 127-132.

Qian Yi \& Xiao Lingong. 1995. Hyolithids. 262 pp. Science Press, Beijing (in Chinese).

Quenstedt, F. A. 1852. Handbuch der Petrefaktenkunde. 792 pp., 62 pl., Verlag der H. Laupp'schen Buchhandlung, Tübingen

- 1867. Handbuch der Petrefaktenkunde. 1239 pp., 100 pl. Verlag der H. Laupp'schen Buchhandlung, Tübingen.

- 1885a. Handbuch der Petrefektenkunde. 1237 pp. Verlag der H. Laupp'schen Buchhandlung, Tübingen.

- 1885b. Handbuch der Petrefaktenkunde. 99 pl. Verlag der H. Laupp'schen Buchhandlung, Tübingen.

Reed, F. R. C. 1909. Lower Palaeozoic Hyolithidae from Girvan. - Transactions of the Royal Society of Edinburgh, 47: $203-222$.

Remelé, A. 1888. Ueber einige Glossophoren aus UntersilurGeschieben des norddeutschen Diluviums. - Zeitschrift der Deutschen Geologischen Gesellschaft 40: 666-670.

- 1889a. Einiges über Euomphalus declivis Rem. und Hyolithus inaequistriatus Rem. - Geologiska Föreningens i Stockholm Förhandlingar 11: 429-433.

- 1889b. Ueber Hyolithus inaequistriatus Rem. - Zeitschrift der Deutschen Geologischen Gesellschaft 41: 547-553.

- 1889c. Ueber einige Glossophoren aus UntersilurGeschieben des norddeutschen Diluviums. Theil II. Bemerkungen über Hyolithes acutus Eichwald. - Zeitschrift der Deutschen Geologischen Gesellschaft 41: 762-770.

Resser, C. E. 1938. Fourth contribution to the nomenclature of Cambrian fossils. - Smithsonian Miscellaneous Collections 97: $1-12$.

Roemer, F. A. 1876. Lethaea paläozoica oder Beschreibung und Abbildung für die einzeln Abtheilungen der paläozischen Formation bezeichnendsten Versteinerungen. Atlas. 
- 1885. Lethaea erratica oder Aufzählung und Beschreibung der in der norddeutschen Ebene vorkommenden Diluvial-Geschiebe nordischer Sedimentär-Gesteine. - Paläontologische Abhandlungen 2 (Heft 5): 1-173 (248-420).

Runnegar, B. N., Pojeta, J., Morris, N. J., Taylor, J. D., Taylor, M. E. \& McClung, G. 1975. Biology of the Hyolitha. Lethaia 8: 181-191.

Sandberger, G. \& Sandberger, F. 1850-1856. Die Versteinerungen des rhenischen Schichtensystems in Nassau. Mit einer kurzgefassten Geognosie dieses Gebietes und mit steter Berücksichtigung analoger Schichten anderer Länder. Kreidel und Niedner, Wiesbaden (1850-1856).

Shaler, N. S. \& Foertse, A. F. 1888. Preliminary description of North Attleboro fossils. - Harvard Museum of Comparative Zoology Bulletin 16: 27-41.

Sinclair, G. W. 1946. Notes on the nomenclature of Hyolithes. Journal of Paleontology 20: 72-85.

Syssoiev, V. A. 1957. K morfologii, sistematike i sistematicheskomu polozheniu khiolitiov [To the morphology, systematics and systematic position of the Hyolithoidea]. - Akademiya Nauk SSSR, Doklady 116: 304-307.

- 1958. Nadotryad Khiolitiov (The superorder Hyolithoidea). - In Luppov, N. P. \& Drushchits, V. V. (eds). Osnovy Paleontologii. Molluski-golovongie II. - Akademiya Nauk SSSR 2: 184-190.

- 1959. Ekologiya khiolitov. - Doklady Akademiya Nauk SSSR 127: 892-895 [translated as Ecology of the hyolithids. - Doklady Akademiya Nauk SSSR 1959: 800802].
- 1960. Klassifikatsiya semeistva Hyolithidae. [Classification of the family Hyolithidae]. - Nauchnyi soobshchinya, Yakutskogo filiala SO AN SSSR 4: 54-56.

- 1962. Khiolity kembriya severnogo sklona Aldanskogo shchita [Cambrian hyolithids from the northern slope of the Aldan shield]. 65 pp., AN SSSR, Yakutskiy filial Sibirskogo otdeleniya, Yakutsk (In Russian).

- 1968. Stratigrafiya i khiolity drevnejshikh sloev nizhnego kembriya Sibirskoj platformy [Stratigraphy and hyoliths of the oldest Lower Cambrian beds of the Siberian platform]. Akademiya Nauk SSSR. 67 pp., Yakutskiy filial Sibirskogo otdeleniya Instituta Geologii, Yakutsk (In Russian).

- 1970. Morfologiya i sistematika khiolitov otryada Ceratothecida [Morphology and systematics of the hyolith order Ceratothecida]. Stratigrafiya i paleontologiya proterozoya kembriya vostoka Sibirskoe platformy: 101-104. Yakutskiy Filial Sibirskogo Otdeleniya Institut Geologii, Yakutsk (In Russian).

- 1972. Biostratigrafiya i khiolity ortotetsiomorfy nizhnego kembriya Sibirskoj platformy [Biostratigraphy and orthothecomorph hyoliths from the Lower Cambrian of the Siberian platform]: 152 pp., Institut Geologii, Yakutskiy Filial Sibirskogo Otdeleniya, Yakutsk.

Walcott, C. D. 1886. Second contribution to the studies on Cambrian faunas of North America. - U.S. Geological Survey Bulletin 30: 1-369.

Wallerius, I. 1895. Undersökningar öfver zonen und med Agnostus laevigatus i Vastergötland jämte en inledande öfversigt af Vastergötlands Paradoxideslager: 73 pp., Gleerup, Lund. 